\title{
Hirschsprung disease, associated syndromes and genetics: a review
}

\author{
J Amiel, ${ }^{1}$ E Sproat-Emison, ${ }^{2} \mathrm{M}$ Garcia-Barcelo, ${ }^{3} \mathrm{~F}$ Lantieri, ${ }^{4,5} \mathrm{G}$ Burzynski, ${ }^{6} \mathrm{~S}$ Borrego, ${ }^{7}$ \\ A Pelet, ${ }^{1}$ S Arnold, ${ }^{2}$ X Miao, ${ }^{3}$ P Griseri, ${ }^{4}$ A S Brooks, ${ }^{6,8} \mathrm{G}$ Antinolo, ${ }^{7} \mathrm{~L}$ de Pontual, \\ M Clement-Ziza, ${ }^{1}$ A Munnich, ${ }^{1}$ C Kashuk, ${ }^{2}$ K West, ${ }^{2}$ K K-Y Wong, ${ }^{3}$ S Lyonnet, ${ }^{1}$ \\ A Chakravarti, ${ }^{2}$ P K-H Tam, ${ }^{3}$ I Ceccherini, ${ }^{4}$ R M W Hofstra, ${ }^{6}$ R Fernandez, ${ }^{7}$ for \\ the Hirschsprung Disease Consortium
}

\begin{abstract}
${ }^{1}$ Université Paris 5-Descartes, Faculté de Médecine; INSERM U-781; AP-HP, Hôpital NeckerEnfant Malades, Paris, France;

${ }^{2}$ McKusick-Nathans Institute of Genetic Medicine, Johns Hopkins University School of Medicine, Baltimore, USA; ${ }^{3}$ Division of Paediatric Surgery, Department of Surgery, Li Ka Shing Faculty of Medicine of the University of Hong Kong, Hong Kong SAR, China; ${ }^{4}$ Laboratorio di Genetica Molecolare, Istituto G. Gaslini, L.go G. Gaslini 5, Italy; ${ }^{5}$ Dipartimento di Scienze della Salute, Sezione Biostatistica, Università degli Studi di Genova, Genova, Italy; ${ }^{6}$ Department of Genetics, University Medical Center Groningen, University of Groningen, Groningen, The Netherlands; ${ }^{7}$ Unidad Clinica de Genetica y Reproduccion. Hospitales Universitarios Virgen del Rocio and Centro de Investigación Biomédica en Red de Enfermedades Raras (CIBERER), Sevilla, Spain;

${ }^{8}$ Department of Clinical

Genetics, Erasmus MC,

Rotterdam, The Netherlands
\end{abstract}

Correspondence to:

Dr Jeanne Amiel, INSERM U781 et Département de Génétique, Hôpital Necker-Enfants Malades, 149, rue de Sèvres 75743 Paris Cedex 15, France; amiel@ necker.fr

Received 21 August 2007 Revised 21 August 2007 Accepted 27 August 2007 Published Online First 26 October 2007

\section{ABSTRACT}

Hirschsprung disease (HSCR, aganglionic megacolon) represents the main genetic cause of functional intestinal obstruction with an incidence of $1 / 5000$ live births. This developmental disorder is a neurocristopathy and is characterised by the absence of the enteric ganglia along a variable length of the intestine. In the last decades, the development of surgical approaches has importantly decreased mortality and morbidity which allowed the emergence of familial cases. Isolated HSCR appears to be a non-Mendelian malformation with low, sex-dependent penetrance, and variable expression according to the length of the aganglionic segment. While all Mendelian modes of inheritance have been described in syndromic HSCR, isolated HSCR stands as a model for genetic disorders with complex patterns of inheritance. The tyrosine kinase receptor RET is the major gene with both rare coding sequence mutations and/or a frequent variant located in an enhancer element predisposing to the disease. Hitherto, 10 genes and five loci have been found to be involved in HSCR development.

Harald Hirschsprung, a Danish paediatrician, first described in 1888 two unrelated boys who died from chronic severe constipation with abdominal distension resulting in congenital megacolon. ${ }^{1}$ The absence of intramural ganglion cells of the myenteric and submucosal plexuses (Auerbach and Meissner plexuses, respectively) downstream of the dilated part of the colon was recognised as the cause of the disease in the 1940s. ${ }^{2}$ This allowed a simple and reliable diagnostic confirmation from rectal suction biopsies using histochemical staining for acetylcholinesterase (AchE). ${ }^{3}$ In 1948, Swenson and Bill developed a surgical procedure ${ }^{4}$ and the survival of patients uncovered familial transmission of Hirschsprung disease (HSCR). ${ }^{5}$ In 1974, Bolande proposed the term neurocristopathy for syndromes or tumours involving the neural crest (NC) cells. ${ }^{6}$ HSCR resulting from an anomaly of the enteric nervous system (ENS) of NC origin is therefore regarded as a neurocristopathy. ${ }^{6-8}$

Isolated HSCR appears to be of complex, nonMendelian inheritance with low, sex-dependent penetrance, variable expression according to the length of the aganglionic segment and suggestive of the involvement of one or more gene(s) with low penetrance. ${ }^{59}$ These parameters must be taken into account for accurate evaluation of recurrence risk in relatives. With a relative risk as high as 200 ,
HSCR appears an excellent model to study common multifactorial diseases. The major susceptibility gene is RET, which is also involved in multiple endocrine neoplasia type 2 (MEN 2) and familial medullary thyroid carcinoma (FMTC). Coding sequence mutations are identified in about $50 \%$ and $15 \%$ of familial and sporadic HSCR cases, respectively. The far most frequent HSCR predisposing event at the RET locus is a haplotype which comprises an SNP lying in an enhancer element of RET intron 1. The identification of modifier genes is currently underway by using various approaches and an international consortium has been settled in 2004 in order to achieve this goal.

HSCR occurs as an isolated trait in $70 \%$ of patients, is associated with a chromosomal abnormality in $12 \%$ of the cases, and with additional congenital anomalies in $18 \%$ of the cases. ${ }^{10-15}$ In the latter group of patients, some monogenic syndromes can be recognised. Indeed, thus far, genetic heterogeneity in HSCR has been demonstrated with 10 specific genes involved. The aim of this paper is to update a 6 year old review on clinical and molecular data about isolated and syndromic HSCR.

\section{DEFINITION AND CLASSIFICATION}

HSCR is a congenital malformation of the hindgut characterised by the absence of parasympathetic intrinsic ganglion cells in the submucosal and myenteric plexuses. ${ }^{2}$ It is regarded as the consequence of the premature arrest of the craniocaudal migration of vagal neural crest cells in the hindgut between the fifth and 12th week of gestation to form the enteric nervous system (ENS) and is therefore regarded as a neurocristopathy. ${ }^{6}{ }^{16}$ While the internal anal sphincter is the constant inferior limit, patients could be classified as short-segment HSCR (S-HSCR: $80 \%$ of cases) when the aganglionic segment does not extend beyond the upper sigmoid, and long-segment HSCR (L-HSCR: 20\% of cases) when aganglionosis extends proximal to the sigmoid. Four HSCR variants have been reported: (1) total colonic aganglionosis (TCA, 3$8 \%$ of cases $)^{17}$; (2) total intestinal HSCR when the whole bowel is involved ${ }^{17}$; (3) ultra-short segment HSCR involving the distal rectum below the pelvic floor and the anus ${ }^{18}$; (4) suspended HSCR, a controversial condition, where a portion of the colon is aganglionic above a normal distal segment. 


\section{CLINICAL FEATURES AND DIAGNOSIS}

In most cases, the diagnosis of HSCR is made in the newborn period $^{15}$ due to intestinal obstruction with the following features: (1) delayed of passage of meconium ( $>24 \mathrm{~h}$ after birth); (2) abdominal distension that is relieved by rectal stimulation or enemas; (3) vomiting; and (4) neonatal enterocolitis. Some patients are diagnosed later in infancy or in adulthood with severe constipation, chronic abdominal distension, vomiting, and failure to thrive. ${ }^{19}$ Finally, although a rare presentation, unexplained perforation of the caecum or appendix should make the diagnosis considered.

On abdominal $x$ ray a distended small bowel and proximal colon, with absence of rectal gas, are common findings. The classical image is a dilated proximal colon with the aganglionic cone narrowing towards the distal gut. On barium enema a small rectum with uncoordinated contractions is seen. The transitional zone represents the site where the narrow aganglionic bowel joins the dilated ganglionic bowel. On a delayed plain $x$ ray taken $24 \mathrm{~h}$ after the enema, barium retention is observed. Anorectal manometry shows absence of relaxation of the internal sphincter (rectal inhibitory reflex) in response to rectal distension. ${ }^{20}$ The reliability of this test becomes excellent from day 12 after birth where the normal rectoenteric reflex is present. ${ }^{21}$ Suction rectal biopsy remains the gold standard for confirming the diagnosis in most cases demonstrating an increased acetyl cholinesterase activity. ${ }^{22}$ Nonetheless, full thickness rectal biopsy is the golden standard in reaching the diagnosis. Furthermore, seromuscular biopsies will be needed at operation to define the proximal limit of the aganglionic segment.

\section{DIFFERENTIAL DIAGNOSES}

Other causes of intestinal obstruction should be discussed when abdominal distension and failure to pass meconium occur in a newborn infant: (1) meconium ileus resulting from cystic fibrosis; (2) intestinal malformations such as lower ileal and colonic atresia, isolated or occasionally associated with HSCR, intestinal malrotation or duplication; (3) ENS anomalies grouped as chronic intestinal pseudo-obstruction syndromes; and (4) functional intestinal obstruction resulting from maternal infection, maternal intoxication or congenital hypothyroidism.

\section{TREATMENT AND PROGNOSIS}

The treatment of HSCR is surgical. After careful preoperative management, the underlying principle is to place the normal bowel at the anus and to release the tonic contraction of the internal anal sphincter. Since the initial protocol of Swenson described in $1948,{ }^{4}$ a series of operative approaches, such as the Soave and Duhamel procedures, have been developed. ${ }^{23}{ }^{24} \mathrm{~A}$ one stage procedure is possible when diagnosis is made early, before colonic dilatation, in short segment disease. Otherwise, a primary colostomy is required. For long segment disease and total colonic aganglionosis, temporary enterostomy is often the first step in management before definitive surgery. Laparoscopic and transanal pull-through techniques have been proposed more recently in HSCR surgery. ${ }^{25}$ These techniques can provide patients with almost scarless surgery. Comparative long term results are pending. ${ }^{26}{ }^{27}$ Neuronal precursor cells isolated from the developing human ENS may open the route to cell therapy ${ }^{28}{ }^{29}$ Fistula or stenosis of the anastomosis and enterocolitis are the main short term complications. ${ }^{30}$ Long term complications include chronic constipation (10-15\%) and soiling. ${ }^{31}{ }^{32}$ Mortality has been below $6 \%$ since the 1980 s and may be related to short term complications or caused by the associated malformations. ${ }^{31}$ However, the treatment of children with TCA remains hazardous. ${ }^{33}{ }^{34}$

\section{EPIDEMIOLOGY}

The incidence of HSCR is estimated at 1/5000 live births. ${ }^{5}$ However, the incidence varies significantly among ethnic groups (1.0, 1.5, 2.1, and 2.8 per 10000 live births in Hispanics, Caucasian-Americans, African-Americans, and Asians, respectively). ${ }^{15} \mathrm{~S}$-HSCR is far more frequent than L-HSCR (80\% and 20\%, respectively). ${ }^{10}{ }^{12}$ There is a sex bias with a preponderance of affected males and a sex ratio of $4 / 1.35$ Interestingly, the male:female ratio is significantly higher for S-HSCR (4.2-4.4) than for L-HSCR (1.2-1.9) (table 1). ${ }^{15} 35$

\section{MOLECULAR GENETICS IN ISOLATED HSCR}

Several genes have been implicated in isolated HSCR, the two major ones being RET and EDNRB.

\section{The RET signalling pathway}

The first susceptibility locus was mapped to $10 \mathrm{q} 11.2$ in multigenerational families segregating HSCR as an incompletely penetrant autosomal dominant trait. ${ }^{36}{ }^{37}$ This region had been targeted because of the observation of an interstitial deletion of chromosome 10q11 in patients with TCA and mental retardation. $^{38}$ The proto-oncogene RET (REarranged during Transfection), identified as disease causing in MEN $2^{39} 40$ and mapping in 10q11.2, was regarded as a candidate gene owing to: (1) co-occurrence of MEN 2A and HSCR in some families; and (2) expression in neural-crest derived cells. Consequently, RET gene mutations were identified in HSCR patients (fig 1). ${ }^{41}{ }^{2}$ Over 100 mutations have been identified including large deletions encompassing the RET gene, microdeletions and insertions, nonsense, missense and splicing mutations. ${ }^{43-46}$ There is no mutational hot spot at variance with MEN 2A, where mutations occur in a cluster of six cysteines (exon 10: residues 609, 611, 618, 620; exon 11: residues 630,634), ${ }^{39} 4047$ and MEN 2B where the mutation is almost unique (M918T, exon 16, tyrosine kinase domain). ${ }^{48-51}$ In vitro, MEN 2 mutations have been shown to be activating mutations leading to constitutive dimerisation of the receptor and to transformation, ${ }^{52}$ while haploinsufficiency is the most likely mechanism for HSCR mutations. ${ }^{53-57}$ Biochemical studies demonstrated variable consequences of some HSCR mutations (misfolding, failure to transport the protein to the cell surface, abolished biological activity)..$^{546}{ }^{58}$ However, a simple activating versus inactivating model of gene action is not sufficient to explain the cooccurrence of HSCR and MEN 2A in patients with a MEN 2A RET gene mutation. ${ }^{51} 59$

Table 1 Epidemiology and recurrence risk figures in HSCR

\begin{tabular}{lll}
\hline & L-HSCR & S-HSCR \\
\hline \% probands & 19 & 81 \\
Sex ratio (male:female) & 1.75 & 5.5 \\
Genetic model & Dominant & Multifactorial or recessive \\
Penetrance (\%) (male:female) & $52: 40$ & $17: 4$ \\
Recurrence risk to sibs* (\%) & & \\
Male proband & $17 / 13$ & $5 / 1$ \\
Female proband & $33 / 9$ & $5 / 3$ \\
\hline
\end{tabular}

Relative risk $=200$.

${ }^{*}$ Recurrence risk is given for male/female siblings, respectively. 
Figure 1 Mutations, haplotypes and recombination spot at the $R E T$ locus.
HSCR mutations

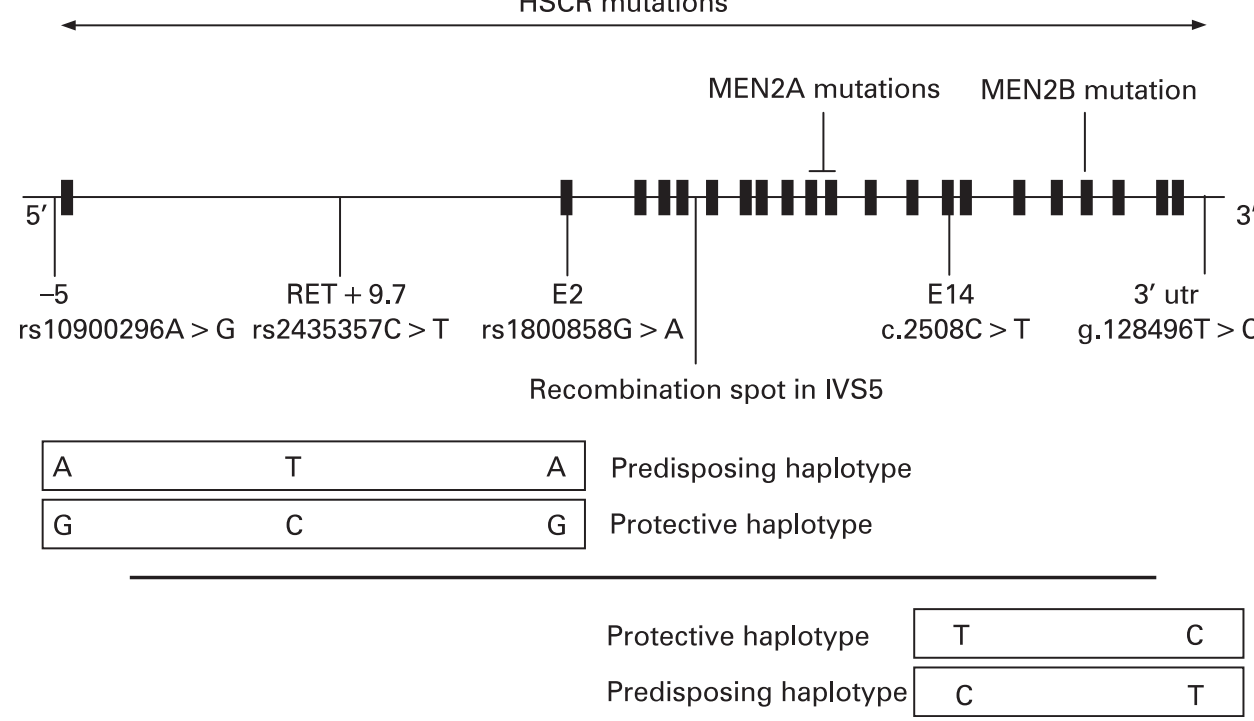

Despite extensive mutation screening, a RET mutation is identified in only $50 \%$ of familial and $15-20 \%$ of sporadic HSCR cases. ${ }^{43} 446061$ However, most families with few exceptions are compatible with linkage at the RET locus. ${ }^{62}$ Case-control and transmission disequilibrium test in several ethnic backgrounds had first pointed to a frequent SNP lying in exon 2 and leading to a silent change as over represented and transmitted in patients (fig 1) ${ }^{63-68}$ Later, the same observation was made for haplotypes comprising this SNP lying in exon 2 and an SNP at -5 from the transcription start site of RET. ${ }^{69-72}$ As there was no convincing evidence for a functional role of these two SNPs, ${ }^{71} 77^{74}$ the most likely hypothesis was that an ancient, low-penetrant founder locus was in linkage disequilibrium with the haplotype of the two SNPs previously identified and distant of about $25 \mathrm{~kb} .{ }^{70}$ Comparative genomics focused on conserved non-coding sequences and an SNP lying in intron 1 was shown associated to HSCR susceptibility, making a 20-fold greater contribution to risk than coding sequence mutations. ${ }^{75}$ This $\mathrm{T}>\mathrm{C}$ SNP lies in an enhancer-like sequence and the $\mathrm{T}$ allele reduces in vitro enhancer activity. ${ }^{75}$ Moreover, this sequence drives reporter expression in tissue consistent with the one of Ret during mouse and zebra fish development. ${ }^{75} 76$ Interestingly, the frequency of the predisposing $\mathrm{T}$ allele varies according to HSCR prevalence in various ethnic backgrounds from about 20$50 \%$ in European and Chinese, respectively. ${ }^{75} 77$ The $\mathrm{T}$ allele high frequency in control populations emphasises, as speculated by the oligogenic model, the pivotal role of the RET gene in HSCR susceptibility despite low penetrance. Finally, the penetrance of the $\mathrm{T}$ allele for the HSCR trait is both dose-dependent and greater in males than in females. ${ }^{75}$ Conversely, an SNP lying in the 3' UTR of the RET gene and lowering stability to RET mRNA degradation has been shown to be under transmitted in HSCR cases. ${ }^{78}$ Again, this SNP lies on a haplotype that is of variable frequency according to ethnicity (about $8-4 \%$ in Caucasian and absent in Chinese). ${ }^{71} 7980$ A recombination spot lies on intron 5 at the RET locus. ${ }^{5966}$

RET is a 1114 amino acid transmembrane receptor with a cadherin-like extracellular domain, a cysteine-rich region and a intracellular tyrosine kinase domain. ${ }^{81}$ The role of Ret in mice development has been expanded to kidney, ${ }^{82-84}$ spermatogenesis $^{85-88}$ and Peyer's patch. ${ }^{80}$ Between the two RET major isoforms (RET9 and RET51) with different C-terminal tails as the result of alternative splicing, RET9 is critical for both kidney and ENS development. ${ }^{91}$

GDNF, known as a major survival factor for many types of neurons, was shown to be the RET ligand by both phenotypic similarities between Ret - / - and Gdnf - / - knock-out mice, ${ }^{92-94}$ and xenopus embryo bioassays. ${ }^{95}$ GDNF is a TGF-B related 211 residue protein, proteolytically cleaved to a 134 residue mature protein that homodimerise. To activate RET, GDNF needs the presence of a glycosylphosphatidylinositol (GPI)-linked coreceptor GFRA1.9697 Four related GPI-linked co-receptors, GFRA1-4, ${ }^{98}$ and four related soluble growth factor ligands of RET have been identified, namely: GDNF, NTN, ${ }^{99}$ persephin $(P S P N)^{100}$ and artemin (ARTN). ${ }^{101}$ Specific combinations of these proteins are necessary for the development and maintenance of both central and peripheral neurons, and all can signal through RET. GDNF mutations have been identified in only six HSCR patients to date, and could be regarded as a rare cause of HSCR $(<5 \%) .{ }^{102-104}$ Moreover, GDNF mutations may not be sufficient to lead to HSCR since $4 / 6$ patients have additional contributory factors, such as RET mutations or trisomy 21. ${ }^{102}{ }^{103}$ Similarly, an NTN mutation has been identified in one family, in conjunction with a RET mutation. ${ }^{105}$ Finally, although Gfra1 homozygous knock-out mice are phenotypically very similar to Ret and Gdnf - / - mice, no GFRA1 mutations have been identified in HSCR patients except a deletion at the locus with incomplete penetrance in one family. ${ }^{69} 106-109$ Worth noting, RET exerts a pro-apoptotic effect that is inhibited by GDNF and some RET gene mutations may impair the control of this activity by GDNF. ${ }^{110}$

\section{The endothelin signalling pathway}

The endothelin pathway was first studied for its vasoconstrictive effect and putative role in hypertension. EDNRB and EDNRA are G-protein-coupled heptahelical receptors that transduce signals through the endothelins (EDN1, 2, 3). ${ }^{111} 112$

A susceptibility locus for HSCR in 13q22 was pointed out for three main reasons: (1) a significant lod-score at 13q22 in a large inbred Old Order Mennonite community with multiple cases of HSCR $^{113-115}$; (2) de novo interstitial deletion of $13 q 22$ in several patients with $\mathrm{HSCR}^{116}$; (3) synteny between the murine locus for piebald-lethal $\left(\mathrm{s}^{\mathrm{l}}\right)$, a model of aganglionosis, and $13 \mathrm{q} 22$ in human. The critical role of the endothelin pathway in HSCR 
was demonstrated with the finding that piebald-lethal was allelic to the Ednrb knock-out mouse and harboured an Ednrb mutation (table 2). ${ }^{117}$ Subsequently, an EDNRB missense mutation was identified in the Mennonite kindred (W276C). ${ }^{118}$ However, the W276C mutation was neither necessary (affected wild-type homozygotes) nor sufficient (non-affected mutant homozygotes) to cause HSCR, and penetrance was sex-dependent (greater in males than in females). ${ }^{118}$ piebald-lethal was considered a mouse model for WS4 in humans, and some of the Mennonite affected individuals had pigmentary anomalies and sensorineural deafness in addition to HSCR. ${ }^{113} 114$ This prompted a screen of the EDNRB gene in WS4, and homozygous mutations in a fraction of WS4 families were found. ${ }^{44}$ At the same time, an Edn3 mutation was identified in the lethal spotting (sl) natural mouse model for WS4 ${ }^{119}$ and, subsequently, EDN3 homozygote mutations were identified in WS4 in humans (table 2). ${ }^{120} 121$

Both EDNRB and EDN3 were screened in large series of isolated HSCR patients. While EDN3 mutations were seldom found, ${ }^{130} E D N R B$ mutations were identified in approximately $5 \%$ of the patients. ${ }^{126-129}$ It is worth mentioning that the penetrance of EDN3 and EDNRB heterozygous mutations is incomplete in those HSCR patients, de novo mutations have not hitherto been observed, and that S-HSCR is largely predominant. Interstitial 13q22 deletions encompassing the EDNRB gene in HSCR patients makes haploinsufficiency the most likely mechanism for HSCR (table 3). Although EDNRB binds all three endothelins, the similarity of phenotype of the Ednrb knock-out mice to that of the Edn3 knock-out mice suggests that EDNRB's major ligand is EDN3.

Preproendothelins are proteolytically cleaved by two related membrane-bound metalloproteases to give rise to the mature 21-residue endothelin. Ece1 processes only Edn1 and Edn3. Ece1 knock-out mice show craniofacial defects and cardiac abnormalities in addition to colonic aganglionosis. ${ }^{132} \mathrm{~A}$ heterozygous
ECE1 mutation has been identified in a single patient combining HSCR, craniofacial and cardiac defects (R742C). ${ }^{131}$

\section{S0X10}

The last known mouse model for WS4 in human is dominant megalon (Dom), homozygous Dom mutation being embryonic lethal. ${ }^{152}$ The Dom gene is Sox10, a member of the SRY (sex determining factor)-like, high mobility group (HMG) DNA binding proteins. ${ }^{125}$ Subsequently, truncating heterozygote SOX10 mutations have been identified in patients with WS4, ${ }^{122-124}$ Yemenite deaf-blind-hypopigmentation syndrome ${ }^{153}$ and WS2 (Bondurand et al in Am J Hum Genet website) but also in patients presenting in addition neurological impairment due to central and peripheral dysmyelination. ${ }^{67} 123$ The latter combination is known as PCWH for Peripheral demyelinationCentral dysmyelinating leucodystrophy-Waardenburg syndrome and Hirschsprung disease. Genotype-phenotype correlation relies on nonsense-mediated decay being effective (WS4) or not (PCWH). ${ }^{154}$ The penetrance of the HSCR trait appears to be high, although sibs sharing a mutation and discordant for HSCR have been described in one family. ${ }^{124}$ Therefore, SOX10 is unlikely to be a major gene in isolated HSCR.

\section{Interaction between pathways}

Ret and Ednrb signalling pathways were considered biochemically independent. However, G-protein-coupled receptors and tyrosine kinase receptors could be engaged in crosstalk. Moreover an HSCR patient heterozygote for weak hypomorphic mutations in both RET and EDNRB has recently been reported. ${ }^{155}$ Each mutation was inherited from a healthy parent. Genetic interactions between EDNRB and RET have been demonstrated in the Mennonite population where HSCR predisposition is high (incidence of 1/500). ${ }^{118} 156$ Finally, no complementation of aganglionosis could be observed in mouse

Table 2 Genes involved in HSCR in humans and known mouse models of megacolon

\begin{tabular}{|c|c|c|c|c|c|c|c|c|}
\hline \multirow[b]{2}{*}{ Gene } & \multicolumn{5}{|l|}{ Human } & \multicolumn{3}{|l|}{ Mouse } \\
\hline & $\begin{array}{l}\text { Map } \\
\text { location }\end{array}$ & $\begin{array}{l}\text { Mode of } \\
\text { inheritance }\end{array}$ & $\begin{array}{l}\text { Phenotype in } \\
\text { mutants }\end{array}$ & Penetrance of the HSCR trait & Refs & $\begin{array}{l}\text { Natural } \\
\text { mutant }\end{array}$ & Knockout & Refs \\
\hline RET & $10 q 11.2$ & $A D$ & HSCR & $\begin{array}{l}70 \% \text { in males and } 50 \% \text { in females } \\
\text { for CDS mutations }\end{array}$ & $43,44,60,61$ & - & $\begin{array}{l}\mathrm{L} \\
\text { Renal agenesis }\end{array}$ & 82 \\
\hline GDNF & $5 p 13$ & $A D$ & HSCR & $\begin{array}{l}5 \text { cases reported } \\
\text { Low penetrance }\end{array}$ & 102-104 & - & $\begin{array}{l}\mathrm{L} \\
\text { Renal agenesis }\end{array}$ & $92-94$ \\
\hline NTN & $19 \mathrm{p} 13$ & $A D$ & HSCR & 1 case reported & 105 & - & - & \\
\hline SOX10 & $22 q 13$ & $A D$ & WS4 & About $80 \%$ & $122-124$ & Dom (AD) & $\begin{array}{l}\mathrm{L} \\
\text { Coat spotting }\end{array}$ & 125 \\
\hline$E D N R B$ & $13 q 22$ & $\mathrm{AR} / \mathrm{AD}$ & WS4/HSCR & Low & $118,126-129$ & $s^{\prime}(\mathrm{AR})$ & $\begin{array}{l}\text { S } \\
\text { Coat spotting }\end{array}$ & 117 \\
\hline EDN3 & $20 q 13$ & $\mathrm{AR} / \mathrm{AD}$ & WS4/HSCR & 1 case reported & 130 & Is (AR) & $\begin{array}{l}\text { S } \\
\text { Coat spotting }\end{array}$ & 119 \\
\hline ECE1 & $1 \mathrm{p} 36$ & $A D$ & $\begin{array}{l}\text { HSCR } \\
\text { CF and cardiac } \\
\text { defect }\end{array}$ & 1 case reported & 131 & - & $\begin{array}{l}\text { S } \\
\text { Coat spotting } \\
\text { Craniofacial defects }\end{array}$ & 132 \\
\hline ZFHX1B (SIP1) & $2 q 22$ & $A D$ & $\begin{array}{l}\text { MCA-MR, facial } \\
\text { gestal, }\end{array}$ & $60 \%$ & $133-135$ & - & Letal at gastrulation & 136 \\
\hline PHOX2B & $4 p 12$ & $A D$ & CCHS & $20 \%$ & 137,138 & - & $\begin{array}{l}\text { TIA } \\
\text { No ANS } \\
\text { Ventilatory anomalies } \\
\text { in Phox2 } \mathrm{b}^{+/-}\end{array}$ & 139,140 \\
\hline TCF4 & $18 q 21$ & $A D$ & $\begin{array}{l}\text { Epileptic } \\
\text { encephalopathy }\end{array}$ & 1 case & $141-143$ & - & $\begin{array}{l}\text { Early letality } \\
\text { Abnormal maturation } \\
\text { of lymphocytes }\end{array}$ & 144,145 \\
\hline
\end{tabular}


Table 3 Recurrent chromosomal anomalies with HSCR as a feature

\begin{tabular}{|c|c|c|c|c|}
\hline Chromosome & Key features & Number of reports & Gene & References \\
\hline Tri 21 & Down syndrome, S-HSCR, 5.5 to 10.5 male: female sex ratio & $2-10 \%$ of HSCR cases & $?$ & $5,11-15$ \\
\hline Del 10q11 & Mental retardation, L-HSCR & 2 cases & RET & 38,146 \\
\hline Del 13q22 & Mental retardation, growth retardation, dysmorphic features, S-HSCR & $>10$ cases & EDNRB & 116 \\
\hline Del 17q21 & & $>1$ case & ? & 149 \\
\hline Dup 17q21-q23 & $\mathrm{MCA} / \mathrm{MR}$ & 4 cases & $?$ & 150 \\
\hline
\end{tabular}

${ }^{*}$ Both S-HSCR and L-HSCR have been observed.

inter crosses between hypomorphic piebald alleles of Ednrb $\left(E_{d n r b}{ }^{s / s}\right)$ and a null allele of Ret. ${ }^{156}$

Sox10 is involved in cell lineage determination and is capable of transactivating MITF synergistically with PAX3. ${ }^{157}$ Similarly, Ednrb transcripts are either absent or drastically reduced in Dom $^{-/-}$and Dom ${ }^{+-}$mice, respectively. ${ }^{158}$ Sox10;Ednrb and Sox10;Edn3 double mutants have a severe ENS defect with no enteric progenitor cells extending beyond the stomach at all embryonic stages studied. ${ }^{159}$ Interestingly, genetic interactions for the HSCR trait have been shown between RET and PHOX2B and $B B S$ genes responsible when mutated for CCHS and BardetBiedl syndromes, respectively. ${ }^{148}$ Such correlation was not found between RET and SOX10. Along these lines, a genome-wide screen aimed at localising modifier genes for the aganglionosis of Dom mice did not point to the Ret locus but, among others, a locus encompassing the PHOX $2 b$ gene. ${ }^{160}$

Taking it all together, several general comments can be made: (1) RET is the major gene in HSCR with either CDS mutations or, more frequently, a low penetrant SNP lying in an enhancer element within intron 1; (2) RET mutation penetrance is incomplete and sex-dependant; (3) genotype-phenotype correlation is poor; 4) HSCR is genetically heterogeneous and due to mutations in distinct pathways; (5) some patients with mutations in more than one HSCR susceptibility gene are known (RET+GDNF, RET+NTN, RET+EDNRB); (6) the RET gene plays a role in HSCR penetrance of some but not all syndromic HSCR (see below).

\section{MULTIGENIC INHERITANCE OF ISOLATED HIRSCHSPRUNG DISEASE}

As mentioned above, RET plays a key role in HSCR genesis and multiple genes may be required to modulate clinical expression. On the other hand, genetic heterogeneity where mutation in one of several genes is sufficient for phenotypic expression of HSCR has been demonstrated (RET, EDNRB, EDN3, ECE1). Segregation studies in HSCR showed that the recurrence risk in siblings varies from $1.5-33 \%$ depending on the gender and the length of the aganglionic segment in the proband, and the gender of the sibling (table 1). ${ }^{55}$ Consequently, HSCR has been assumed to be a sex modified multifactorial disorder, the effect of genes playing a major role as compared to environmental factors (relative risk of 200).

According to the segregation analysis where an autosomal dominant model in L-HSCR and a multifactorial model in SHSCR were more likely, different approaches have been chosen to test these hypotheses in L-HSCR and S-HSCR independently.

a. Linkage analysis in 12 HSCR families with three or more affected individuals in two or more generations where LHSCR is largely predominant. ${ }^{62}$ All but one family showed linkage to the RET locus. Mutational analysis identified a nonsense or missense mutation at highly conserved residue in six families, a splice mutation in two families and no coding sequence variation in three families. Linkage to a novel locus in 9q31 was identified only in families with no or hypomorphic RET gene mutation. Therefore, a severe RET mutation may lead to phenotypic expression by haploinsufficiency while hypomorphic RET mutations would require the action of other mutations.

b. A sib-pair analysis in 49 families with S-HSCR probands. ${ }^{161}$ This studies shows that only three loci on chromosomes $3 p 21,10 q 11$ and 19q12 are both necessary and sufficient to explain the incidence and sibling recurrence risk in HSCR. A multiplicative risk across loci with most affected individuals being heterozygotes at all three loci seems the best genetic model. Finally, linkage to 9q31 was confirmed in the sibpairs with no or hypomorphic RET mutation.

c. A genome-wide association study was conducted in 43 Mennonite family trios and identified a susceptibility locus on $16 \mathrm{q} 23$ in addition to the loci of the two predisposing genes in this population (RET and EDNRB at 10q11.2 and $13 q 22$, respectively). ${ }^{156}$

d. Linkage analysis in a multigenerational HSCR family where the RET gene had been previously excluded, showed linkage to $4 \mathrm{q} 31-\mathrm{q} 32 .{ }^{162}$

The route to the identification of modifier genes is now based on various approaches. A differential screen for ENS expressed genes was conducted by a 22000 probe DNA micro array of embryonic $\mathrm{Ret}^{+/+}$and $\mathrm{Ret}^{-/-}$mice and identified over 300 genes over expressed in $\mathrm{Ret}^{+/+}$mice. ${ }^{29}$ These genes are regarded as critical for enteric neurogenesis and therefore potential candidates in HSCR. By synteny, some lie at candidate modifier loci for isolated HSCR. Other approaches undertook by the HSCR Consortium are microarrays of RNAs from microdissection of enteric neurons and glia on the one hand and $500 \mathrm{k}$ SNP genotyping in trios on the other hand.

\section{SYNDROMIC HSCR}

HSCR occurs as an isolated trait in $70 \%$ of cases. A chromosomal abnormality is associated in $12 \%$ of cases, trisomy 21 being by far the most frequent (>90\%). Associated congenital anomalies are found in 18\% of the HSCR patients. The one occurring at a frequency above that expected by chance include gastrointestinal malformation, cleft palate, polydactyly, cardiac septal defects and craniofacial anomalies. ${ }^{13}{ }^{14}$ The higher rate of associated anomalies in familial cases than in isolated cases $(39 \%$ vs $21 \%)$ strongly suggests syndromes with Mendelian inheritance. ${ }^{14}$ Assessment of all HSCR patients by a trained dysmorphologist should provide a careful evaluation for recognisable syndromes. 


\section{Chromosomal anomalies}

A large number of chromosomal anomalies have been described in HSCR patients. Free trisomy 21 (Down syndrome) is by far the most frequent, involving $2-10 \%$ of ascertained HSCR cases. ${ }^{511-15}$ In these cases, both the unbalanced sex ratio (5.510.5:1 male:female) and the predominance of S-HSCR are even greater than in isolated HSCR. Over-expression of gene(s) on chromosome 21 and predisposing to HSCR has been hypothesised and a susceptibility gene mapping to 21 q22 postulated in a Mennonite kindred. ${ }^{114}$ However, these data were not confirmed. ${ }^{156}$ Hitherto, coding sequence mutations in genes predisposing to HSCR, RET, EDNRB and GDNF, respectively, were found in only three patients with Down syndrome and HSCR. ${ }^{103} 163$ However, the common HSCR predisposing RET hypomorphic allele is over represented in patients with Down syndrome and HSCR when compared to patients without HSCR. ${ }^{148}$

Some chromosomal interstitial deletions reported in combination with HSCR, have been important for the identification of HSCR predisposing genes, namely: (1) 10q11.2 interstitial deletion observed in a few patients with L-HSCR or TCA ${ }^{38} 146$ leading to the mapping and identification of the first HSCR predisposing gene (RET); (2) 13q22.1-32.1 interstitial deletion in patients with S-HSCR leading to the mapping of the second gene $(E D N R B)^{164-166}$; (3) 2q22-23 interstitial deletion syndrome in patients with a multiple congenital anomaly-mental retardation (MCA-MR) syndrome with HSCR or severe chronic constipation further delineated as Mowat-Wilson syndrome (table 3), ${ }^{133} 134147$ leading to the identification of the ZFHX1B gene (previously named SIP1 gene). ${ }^{135}$

Rarer chromosomal anomalies reported in combination with HSCR are summarised in table 3. DiGeorge syndrome, mosaic trisomy 8, XXY chromosomal constitution, partial duplication of chromosome $2 q$, tetrasomy $9 p$, and $20 p$ deletion, have been observed at least once with HSCR. Interestingly, a patient with S-HSCR, postnatal growth retardation, mild developmental delay, dysmorphic facial features and a deletion at $4 \mathrm{p} 12$ encompassing the PHOX2B gene has been reported. ${ }^{167}$

\section{Syndromes and associated anomalies}

Both the recognition of known entities and the delineation of novel ones including HSCR as a feature are of importance for disease prognosis, accurate genetic counselling and search for candidate genes. Syndromes reported associated with HSCR are numerous. Some associations are well characterised with a penetrance of HSCR ranging from $5 \%$ to $>80 \%$ (table 2 ). For rare disorders, whether an association with HSCR observed once is meaningful or occurred by chance alone is not possible to decide. These conditions are summarised in table 4. Both frequent and occasional associations may be of interest for the identification of susceptibility genes to HSCR.

\section{Syndromes frequently associated with HSCR: neurocristopathies}

The NC is a transient and multipotent embryonic structure that gives rise to neuronal, endocrine and paraendocrine, craniofacial, conotruncal heart and pigmentary tissues. ${ }^{7}$ Neurocristopathies encompass tumours, malformations and single or multifocal anomalies of tissues mentioned above with various combinations. MEN 2, neuroblastoma (NB) conotroncal heart defects and Waardenburg syndromes illustrate each of these categories, and are associated with HSCR.
Multiple endocrine neoplasia type 2 and familial medullary thyroid carcinoma

Familial medullary thyroid carcinoma (FMTC), MEN type 2A (MEN 2A) and type 2B (MEN 2B) are cancer predisposition syndromes with an autosomal dominant mode of inheritance. MEN 2A is defined by an age-related predisposition to medullary thyroid carcinoma (MTC, $70 \%$ by the age of 70 years), pheochromocytoma (50\% of cases) and hyperplasia of the parathyroid glands (15-35\%). In addition to MTC and pheochromocytoma, individuals with MEN 2B present with oral neuromas, marfanoid habitus and hyperganglionosis of the hindgut. ${ }^{208}$ Germline missense mutations of the RET gene have been identified in MEN 2A, MEN 2B and FMTC. Both FMTC and MEN 2A can be associated with HSCR in some families. ${ }^{47}{ }^{175-181}$ Interestingly, these families present a germline RET mutation of the MEN 2A or FMTC type (see below). ${ }^{47}{ }^{176-181}$ This raises the question of whether all individuals with HSCR, regardless of non-contributive family history, should be screened for RET exon 10 and 11 mutations to rule out cancer predisposition (3/160 cases in our series with C609W, C611R and C620R RET gene mutations, respectively).

\section{Neuroblastoma}

Neuroblastoma (NB) is the most frequent solid tumour in childhood with an incidence of 1/10 000. The tumour can arise at any site of the sympathetic chain or the adrenal medulla (both originating from NCC). In some families, tumour predisposition segregates through generations with incomplete penetrance. ${ }^{209-211} \mathrm{NB}$ is found associated to HSCR and congenital central hypoventilation (CCHS, see below) in various combinations and, in each combination, heterozygous mutations of the paired-like homeobox $2 \mathrm{~B}$ gene (PHOX2B) have been identified. ${ }^{137}$ 212-217 However, germeline PHOX2B mutations remain rare in sporadic, isolated NB. ${ }^{215} 216$

Congenital central hypoventilation syndrome (CCHS, MIM 209880). Initially termed Ondine's curse, CCHS is a rare, life-threatening condition characterised by abnormal ventilatory response to hypoxia and hypercapnia due to failure of autonomic respiratory control. ${ }^{218} \mathrm{CCHS}$ is not per se a neurocristopathy due to the involvement of both the central and peripheral autonomic nervous system. CCHS patients often present symptoms resulting from a broader dysfunction of the autonomous nervous system and predisposition to neural crest cell derived tumours (5-10\% of CCHS cases, neuroblastoma, ganglioblastoma, ganglioneuroma). ${ }^{209}$ 219-221 Haddad syndrome (MIM 209880) is defined by the association of HSCR and CCHS and is found in about $20 \%$ of CCHS patients. ${ }^{138} 172173$ In these cases, L-HSCR (including TCA) is the most frequent, and the sex ratio is almost equal at variance to what is observed in isolated HSCR. ${ }^{22}$ PHOX2B is the disease causing gene with de novo heterozygous mutation in the proband, ${ }^{174}$ the far most frequent being in frame duplication leading to polyalanine expansion. ${ }^{23} 224$ Parents of patient with molecularly proven CCHS must be tested for accurate genetic counselling as about $10 \%$ carry a somatic mosaic ${ }^{137}$ and some parents may develop late onset CHS. ${ }^{225}$ Finally, genotype/phenotype correlations allow the detection of patients with a high risk to develop tumours (and carry a frameshift mutation) and reassurance about tumour predisposition to those carrying a polyalanine expansion. ${ }^{137}$ 
Table 4 Syndromes associated with HSCR

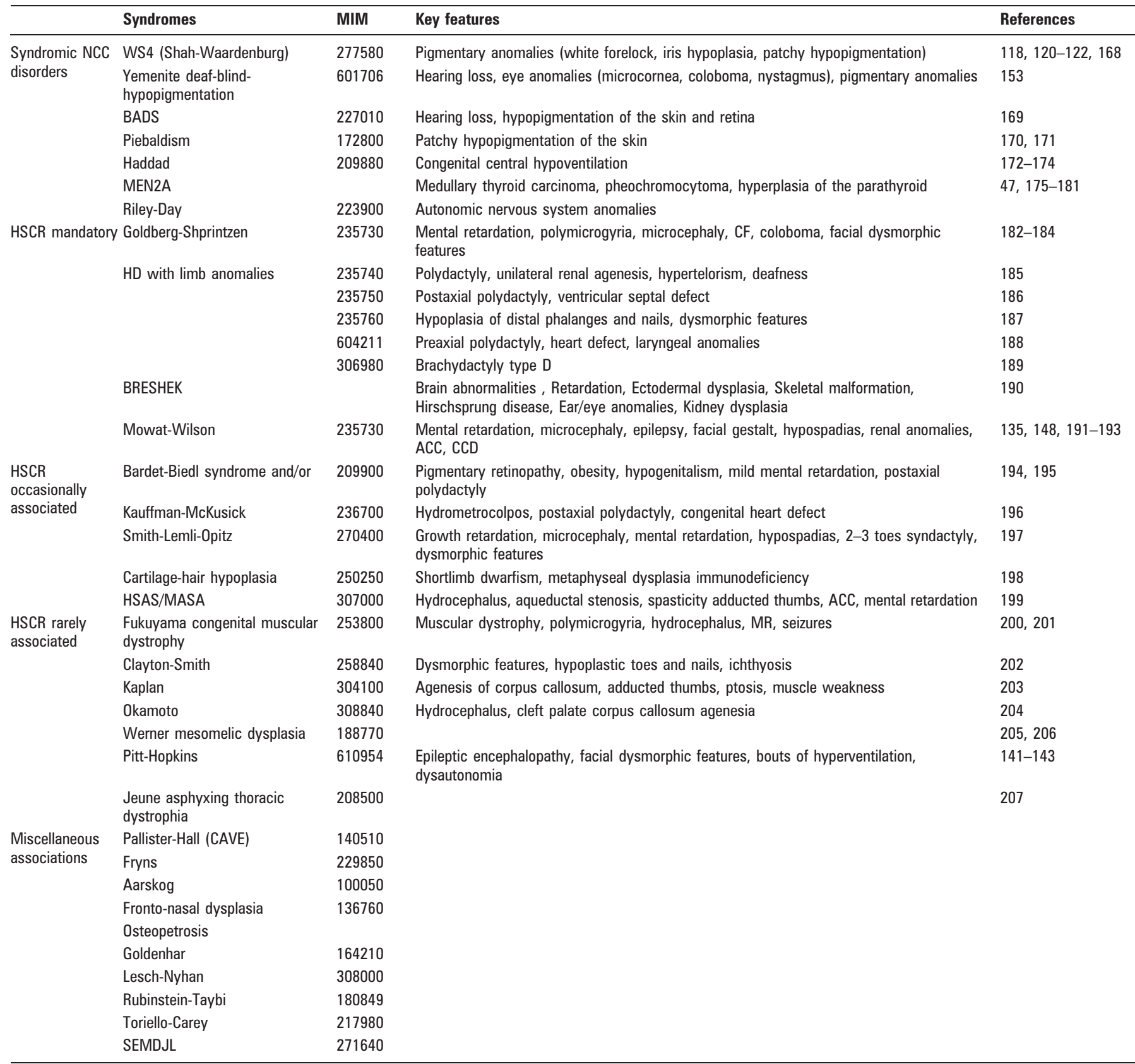

Adapted from: Scriver CM et al. The metabolic and molecular bases of inherited diseases. 8th ed. McGraw-Hill, pp 6231-55.

Waardenburg syndromes (WS) and related pigmentary anomalies WS, an autosomal dominant condition, is by far the most frequent condition combining pigmentary anomalies and sensorineural deafness (1/50 000 live births and $2-5 \%$ of all congenital deafness), resulting from the absence of melanocytes of the skin and the stria vascularis of the cochlea. ${ }^{226}$ WS is clinically and genetically heterogeneous (MIM 193500, MIM 148820, MIM 193510). ${ }^{227}$ The combination of HSCR with WS defines the WS4 type (Shah-Waardenburg syndrome, MIM 277580), a genetically heterogeneous condition. Indeed, homozygous mutations of the endothelin pathway ${ }^{118} 120121168$ and heterozygous SOX10 mutations have been identified in WS4 patients. ${ }^{122}$ Patients carrying a SOX10 mutation may also present with CNS involvement including seizures, ataxia, and demyelinating peripheral and central neuropathies ${ }^{123} 228$ and WS2 (Bondurand et al in Am J Hum Genet website).
Related syndromes associating pigmentary anomalies and HSCR include: (1) Yemenite deaf-blind hypopigmentation syndrome (MIM 601706), a SOX10 mutation having been reported in one of these families ${ }^{153}$; (2) Black Locks-AlbinismDeafness syndrome (BADS, MIM 227010) with TCA-HSCR in one case ${ }^{169}$; (3) aganglionic megacolon associated with familial piebaldism (MIM 172800) ${ }^{170171}$; (4) HSCR and profound congenital deafness but with no other WS features has also been reported. ${ }^{229}$

\section{Other neurocristopathies}

Familial dysautonomia syndrome (FDS, Riley-Day syndrome, MIM 223900) has been reported once in association with HSCR. Although it could have arisen by chance alone, it is interesting to note that FDS maps to 9q31 where a susceptibility locus for HSCR has been identified. Other occasional associations 
reported thus far include cleft lip with or without cleft palate, ${ }^{230}$ neural tube defects (myelomeningocoele) ${ }^{231}$ and neurofibromatosis type I. ${ }^{210}$ The significance of these associations is not yet established.

\section{Other syndromes with HSCR as a frequent feature Mowat-Wilson syndrome (MIM 235730)}

Mowat-Wilson syndrome (MWS) is an MCA-MR condition first delineated among the heterogeneous group of patients with HSCR and MR. ${ }^{134}$ The condition is associated with microcephaly, epilepsy, a facial gestalt and severe mental retardation. The spectrum of possibly associated malformations is wide and encompasses, in decreasing frequency order, hypospadias, renal anomalies, congenital cardiac defect, agenesis/hypoplasia of the corpus callosum and HSCR. ${ }^{148}{ }^{193}$ Heterozygous de novo deletions encompassing the ZFHX1B (zinc finger homeo box 1B) gene or truncating mutations within the gene are found in over 100 cases. ${ }^{135} 191192$ Some rare splicing and missense mutations have also been reported. ${ }^{148}$ Loss of function by haploinsufficiency is the disease causing mechanism in humans. ZFHX1B acts as a transcriptional repressor of smad protein targets and has key functions in early embryonic development in several animal models. ${ }^{94}{ }^{136}{ }^{232} \mathrm{~A}$ knock-out restricted to NCC precursors in mice demonstrated a wide range of anomalies in NCC derivatives. ${ }^{233}$

\section{Goldberg-Shprintzen syndrome (MIM 609460).}

This autosomal recessive MCA-MR syndrome combines HSCR, moderate mental retardation, microcephaly, polymicrogyria, facial dysmorphic features (hypertelorism, prominent nose, synophrys, sparse hair), cleft palate and iris coloboma. ${ }^{182} 183$ The disease causing gene KIAA1279 has been identified in a large consanguineous family and encodes a protein of unknown function. ${ }^{184}$ GSS is a rare condition within the group of patients with MR and HSCR. Several reports with variable association of microcephaly, iris coloboma, cleft palate and mental retardation, and regarded as possible variants GSS, are unlikely allelic conditions. ${ }^{234} 235$

\section{HSCR with limb anomalies}

Several rare syndromes with HSCR and distal limb anomalies (polydactyly or hypoplasia) have been reported. These are: (1) HSCR with polydactyly, unilateral renal agenesis, hypertelorism and congenital deafness (MIM 235740) ${ }^{185}$; (2) HSCR, postaxial polydactyly and ventricular septal defects (MIM 235750) ${ }^{186}$; (3) HSCR, hypoplasia of the distal phalanges and nails and mild dysmorphic features (MIM 235760) ${ }^{187}$; (4) HSCR with preaxial polydactyly, heart defect and laryngeal anomalies $\left(\right.$ MIM 604211) ${ }^{188}$; (5) HSCR with brachydactyly type D (MIM 306980) ${ }^{189}$; (6) HSCR with brachydactyly, macrocephaly and vertebrae anomalies ${ }^{190}$; (7) BRESHEK syndrome ${ }^{236}$; and (8) Werner mesomelic dysplasia. ${ }^{205} 206$

\section{Bardet-Biedl syndrome (MIM 209900) and McKusick-Kauffman syndrome (MIM 236700)}

Bardet-Biedl syndrome (BBS) is characterised by progressive pigmentary retinopathy, obesity, hypogenitalism, renal involvement (including cysts, renal cortical loss or reduced ability to concentrate urine), mild mental retardation and postaxial polydactyly of the hands and feet. BBS is genetically heterogeneous with at least 12 loci and 10 genes identified, all involved in ciliary function. ${ }^{237}$ HSCR has been reported in several BBS cases. ${ }^{194}{ }^{195}$ McKusick-Kauffman syndrome (MKKS) is a rare condition, allelic to BBS and characterised by hydrometrocolpos, postaxial polydactyly and congenital heart defect. HSCR is found in $10 \%$ of cases. ${ }^{196}$ Mutations in the MKKS/BBS6 gene, encoding a chaperonin protein, were identified in some BBS patients confirming that both conditions are allelic. ${ }^{238} 239$ Jeune syndrome, also ascribed to a gene involved in the ciliary function, has been occasionally associated to HSCR. ${ }^{207}$

\section{Smith-Lemli-Opitz syndrome (MIM 270400)}

Smith-Lemli-Opitz syndrome (SLO) is characterised by pre- and postnatal growth retardation and microcephaly, severe mental retardation, facial dysmorphic features, hypospadias and syndactyly between toes 2 and 3. SLO results from cholesterol metabolic impairment with mutation of the 7-dehydro-cholesterol reductase gene (DHCR7, chromosome 11q12-q13). ${ }^{240}{ }^{241}$ HSCR is observed in a significant number of severe SLO patients. ${ }^{197}$

\section{Cartilage-hair hypoplasia syndrome (MIM 250250)}

The skeletal dysplasia cartilage-hair hypoplasia syndrome $(\mathrm{CHH})$, first described in the Old Order Amish community, combines metaphyseal dysplasia with short limb dwarfism, fine, sparse and blond hair, transient macrocytic anaemia and immunodeficiency. HSCR is associated in approximately $10 \%$ of the cases. ${ }^{198}$ The gene RMRP has been mapped to chromosome 9p13. ${ }^{242}$ Interestingly, HSCR has been reported in the Holmgren-Connor syndrome (MIM 211120) which may be allelic to $\mathrm{CHH}$.

The RET gene plays a pivotal role in both isolated and syndromic HSCR. Indeed, epistatic interactions with the common RET hypomorphic allele has been demonstrated for HSCR predisposition in Down, CCHS and BBS..$^{148} 243$ Conversely, the role of the RET hypomorphic allele is not significant in MWS and WS4 due to SOX10 mutation. ${ }^{148}$ Of note, a case-control study in a Chinese population identified an SNP in intron 2 of PHOX2B (IVS2+100) as over represented in the HSCR group of patients. ${ }^{24}$

\section{Miscellaneous observations}

This can be include; (1) syndromes with myopathy ${ }^{200201}$; (2) syndromes with dermatological findings ${ }^{202}$; and (3) syndromes with central nervous system anomalies, among which the HSAS/MASA spectrum ascribed to mutations in the X-linked L1CAM gene. Indeed, at least five different mutations in L1CAM have been identified in patients with hydrocephalus and HSCR. ${ }^{199}$ Interestingly, L1cam is an ENS-expressed gene. ${ }^{29}$ The question of L1CAM being a modifier gene in HSCR has been raised with no definitive answer given thus far. ${ }^{245} 246$ Other rare associations include the finding of HSCR with Fryns, Aarskog, Jeune asphyxing thoracic dystrophia, Joubert, frontonasal dysplasia, osteopetrosis, Goldenhar, Lesch-Nyhan, Rubinstein-Taybi, Toriello-Carey, Pallister-Hall, spondylo-epimetaphyseal dysplasia with joint laxity (SEMDJL, MIM 271640), persistent mullerian duct syndromes, and asplenia with cardiovascular anomaly.

\section{Associated anomalies}

A wide spectrum of additional isolated anomalies have been described among HSCR cases, with an incidence varying from 5-30\% according to series. ${ }^{10} 1113247-250$ No constant pattern is observed and these anomalies include distal limb, sensorineural, skin, central nervous system, genital, kidney and cardiac malformations. However, cardiac defects, and mostly atrio- or 
ventriculoseptal defects, are found with an incidence of $5 \%$ of HSCR cases, once removed patients with trisomy 21 and HSCR. Renal dysplasia or agenesis was reported in FMTC ${ }^{251}$ and found in $4.4 \%$ in a series of 160 HSCR cases and may still be underestimated (personal data). This is of interest since homozygous knock-out mice for genes involved in the Ret signalling pathway present with renal agenesia/dysplasia in addition to megacolon. ${ }^{82}$ Genital anomalies including hypospadias are reported in up to $2-3 \%$ of HSCR patients. Gastrointestinal malformations such as Meckel diverticulum, pyloric stenosis, single umbilical arteria, inguinal hernia or small bowel atresia are also found. ${ }^{252-254}$ Finally, facial dysmorphic features seem extremely frequent when looked for. These data highlight the importance of a careful assessment by a clinician trained in dysmorphology for all newborns diagnosed with HSCR. Skeletal $x$ ray, cardiac and urogenital ultrasound survey should be systematically performed. The observation of one additional anomaly to HSCR should prompt chromosomal studies and/or molecular karyotyping.

The unanswered question of sex-dependent penetrance in HSCR Expression and penetrance of a RET mutation is variable and sex-dependent within HSCR families. In large series, the estimated penetrance is $72 \%$ in males and $51 \%$ in females. ${ }^{44}$ Accordingly, the penetrance of the HSCR predisposing $\mathrm{T}$ allele for the HSCR trait is greater in females than in males. ${ }^{75} \mathrm{~A}$ significant parent-of-origin effect at the RET locus, $78 \%$ of shared RET alleles by affected sibs being maternally derived, could explain the sex difference in HSCR expression. Epigenetic effects at the RET locus have been hypothesised. Of note, a sex difference in disease expressivity (that is, length of the aganglionic segment) of $\operatorname{Ret}^{+/-}$Ednrb ${ }^{\mathrm{s} / \mathrm{s}}$ mice has been observed. ${ }^{255}$ None of the genome wide scans performed in HSCR families identified a locus on the X chromosome thus far. However, a differential screen for ENS expressed genes performed in mice pointed to several X-linked genes. ${ }^{29}$ Finally, the observation of a skewed sex ratio in RET-independent syndromic HSCR (that is, MWS and WS4) suggests that the sex bias observed cannot entirely rely on a gender effect at the RET locus. ${ }^{148}$

\section{GENETIC COUNSELLING}

HSCR is a sex-modified multifactorial congenital malformation with an overall recurrence risk in sibs of the proband of $4 \%$ (relative risk $=200$ ). In isolated HSCR, adequate relative risk figures will be provided by taking into account the sex and length of the aganglionic segment in the proband and the gender of the sibling (2-33\%). According to Carter's paradox, the highest recurrence risk is for a male sibling of a female proband with L-HSCR (table 1). According to poor genotype-phenotype correlation thus far, the benefit of mutation screening for HSCR patients appears low except for systematic testing of exon 10 and 11 of the RET gene, owing to cancer predisposition of MEN2A mutations. This, however, is still not routine practice in most countries.

Many HSCR cases are associated with other congenital anomalies. In these cases, the long term prognosis is highly dependent on the severity of the associated anomalies. Several known syndromes have straight Mendelian inheritance. This emphasises the importance of careful assessment by a clinician trained in syndromology of all newborns diagnosed with HSCR.

Acknowledgements: We thank the HSCR patients and their families, and the French Hirschsprung Disease Association (AFMAM), for their cooperation and active participation over 10 years. We sincerely acknowledge colleagues from all over the world for providing us samples as well as all the students and collaborators of the groups who joined in a consortium on Hirschsprung disease.

Competing interests: None declared.

\section{REFERENCES}

1. Hirschsprung $\mathbf{H}$. Stuhlträgheit neugeborener infolge von dilatation und hypertrophic des colons. Jb inderheilk 1888;27:1.

2. Whitehouse $\mathbf{F}$, Kernohan J. Myenteric plexuses in congenital megacolon; study of 11 cases. Arch Int Med 1948;82:75.

3. Meier-Ruge W, Lutterbeck PM, Herzog B, Morger R, Moser R, Scharli A. Acetylcholinesterase activity in suction biopsies of the rectum in the diagnosis of Hirschsprung's disease. J Pediatr Surg 1972;7:11-7

4. Swenson 0. Early history of the therapy of Hirschsprung's disease: facts and personal observations over 50 years. J Pediatr Surg 1996;31:1003-8.

5. Bodian M, Carter C. A family study of Hirschsprung disease. Ann Hum Genet 1963;26:261.

6. Bolande RP. The neurocristopathies; a unifying concept of disease arising in neural crest maldevelopment. Hum Pathol 1974:5:409-20.

7. Le Douarin N, Kalcheim C. The neural crest. 2nd ed. Cambridge: Cambridge University Press, 1999.

8. Iwashita T, Kruger GM, Pardal R, Kiel MJ, Morrison SJ. Hirschsprung disease is linked to defects in neural crest stem cell function. Science 2003;301:972-6.

9. Badner JA, Chakravarti A. Waardenburg syndrome and Hirschsprung disease: evidence for pleiotropic effects of a single dominant gene. Am J Med Genet 1990;35:100-4.

10. Passarge E. The genetics of Hirschsprung's disease. Evidence for heterogeneous etiology and a study of sixty-three families. N Eng/ J Med 1967;276:138-43.

11. Goldberg EL. An epidemiological study of Hirschsprung's disease. Int J Epidemiol 1984;13:479-85.

12. Garver KL, Law JC, Garver B. Hirschsprung disease: a genetic study. Clin Genet 1985:28:503-8.

13. Spouge D, Baird PA. Hirschsprung disease in a large birth cohort. Teratology 1985; 32:171-7.

14. Brooks AS, Breuning MH, Meijers C. Spectrum of phenotypes associated with Hirschsprung disease: an evaluation of 239 patients from a single institution. The Third International Meeting: Hirschsprung disease and related neurocristopathies.Evian, France, 1998.

15. Torfs CP. An epidemiological study of Hirschsprung disease in a multiracial California population. The Third International Meetings: Hirschsprung disease and related neurocristopathies.Evian, France, 1998.

16. Taraviras $\mathbf{S}$, Pachnis V. Development of the mammalian enteric nervous system Curr Opin Genet Dev 1999:9:321.

17. Nihoul-Fékété C, Ricour C, Martelli H, Lortat Jacob S, Pellerin D. Total colonic aganglionosis (with or without ileal involvement): a review of 27 cases. J Pediatr Surg 1986;21:251.

18. Neilson IR, Yazbeck S. Ultrashort Hirschsprung's disease: myth or reality. J Pediatr Surg 1990;25:1135-8.

19. Parc R, Berrod JL, Tussiot J, Loygue J. [Megacolon in adults. Apropos of 76 cases] Ann Gastroenterol Hepatol (Paris) 1984;20:133-41.

20. Emir H, Akman M, Sarimurat N, Kilic N, Erdogan E, Soylet Y. Anorectal manometry during the neonatal period: its specificity in the diagnosis of Hirschsprung's disease. Eur J Pediatr Surg 1999;9:101-3.

21. Lopez Alonso M. [Manometric study in the newborn]. Cir Pediatr 1992;5:66-71.

22. Kurer MH, Lawson J0, Pambakian H. Suction biopsy in Hirschsprung's disease. Arch Dis Child 1986;61:83-4.

23. Soave F. Hirschsprung's disease. Technique and results of Soave's operation. Br J Surg 1966;53:1023-7.

24. Newbern WR. Hirschsprung's disease-the Duhamel modification Am J Gastroenterol 1967;47:61-8.

25. Albanese CT, Jennings RW, Smith B, Bratton B, Harrison MR. Perineal one-stage pull-through for Hirschsprung's disease. J Pediatr Surg 1999;34:377-80.

26. Langer JC, Durrant AC, de la Torre L, Teitelbaum DH, Minkes RK, Caty MG, Wildhaber BE, Ortega SJ, Hirose S, Albanese CT. One-stage transanal Soave pullthrough for Hirschsprung disease: a multicenter experience with 141 children. Ann Surg 2003;238:569-83; discussion 583-5.

27. El-Sawaf MI, Drongowski RA, Chamberlain JN, Coran AG, Teitelbaum DH. Are the long-term results of the transanal pull-through equal to those of the transabdominal pull-through? A comparison of the 2 approaches for Hirschsprung disease. J Pediatr Surg 2007;42:41-7; discussion 47.

28. Rauch U, Hansgen A, Hagl C, Holland-Cunz S, Schafer KH. Isolation and cultivation of neuronal precursor cells from the developing human enteric nervous system as a tool for cell therapy in dysganglionosis. Int J Colorectal Dis 2006;21:554-9.

29. Heanue TA, Pachnis V. Enteric nervous system development and Hirschsprung's disease: advances in genetic and stem cell studies. Nat Rev Neurosci 2007;8:46679 .

30. Hackam DJ, Filler RM, Pearl RH. Enterocolitis after the surgical treatment of Hirschsprung's disease: risk factors and financial impact. J Pediatr Surg 1998;33:830-3.

31. Yanchar NL, Soucy P. Long-term outcome after Hirschsprung's disease: patients perspectives. J Pediatr Surg 1999;34:1152-60. 
32. Moore SW, Albertyn R, Cywes S. Clinical outcome and long-term quality of life after surgical correction of Hirschsprung's disease. J Pediatr Surg 1996;31:1496502

33. Jasonni V, Martucciello G. Total colonic aganglionosis. Semin Pediatr Surg 1998; 7:174-80.

34. Tsuji H, Spitz L, Kiely EM, Drake DP, Pierro A. Management and long-term follow-up of infants with total colonic aganglionosis. J Pediatr Surg 1999:34:158-61; discussion 162

35. Badner JA, Sieber WK, Garver KL, Chakravarti A. A genetic study of Hirschsprung disease. Am J Hum Genet 1990;46:568-80.

36. Lyonnet S, Bolino A, Pelet A, Abel L, Nihoul-Fekete C, Briard ML, Mok-Siu V, Kaariainen $\mathrm{H}$, Martucciello $\mathrm{G}$, Lerone $\mathrm{M}$, et al. A gene for Hirschsprung disease maps to the proximal long arm of chromosome 10. Nat Genet 1993;4:346-50.

37. Angrist M, Kauffman E, Slaugenhaupt SA, Matise TC, Puffenberger EG, Washington SS, Lipson A, Cass DT, Reyna T, Weeks DE, et al. A gene for Hirschsprung disease (megacolon) in the pericentromeric region of human chromosome 10. Nat Genet 1993:4:351-6.

38. Martucciello G, Biocchini M, Dodero P, Cirillo M, Puliti A, Gimelli G. Total colonic aganglionosis associated with interstitial deletion of the long arm of chromosome 10. Pediatr Surg Int 1992; 7:308

39. Mulligan LM, Kwok JB, Healey CS, Elsdon MJ, Eng C, Gardner E, Love DR, Mole SE, Moore JK, Papi L. Germ-line mutations of the RET proto-oncogene in multiple endocrine neoplasia type 2A. Nature 1993:363:458-60.

40. Donis-Keller H, Dou S, Chi D, Carlson KM, Toshima K, Lairmore TC, Howe JR, Moley JF, Goodfellow P, Wells SA. Mutations in the RET proto-oncogene are associated with MEN 2A and FMTC. Hum Mol Genet 1993;2:851-6.

41. Edery P, Lyonnet S, Mulligan LM, Pelet A, Dow E, Abel L, Holder S, Nihoul-Fekete C, Ponder BA, Munnich A. Mutations of the RET proto-oncogene in Hirschsprung's disease. Nature 1994;367:378-80

42. Romeo G, Ronchetto P, Luo Y, Barone V, Seri M, Ceccherini I, Pasini B, Bocciardi R, Lerone $M$, Kaariainen $H$, et al. Point mutations affecting the tyrosine kinase domain of the RET proto- oncogene in Hirschsprung's disease. Nature 1994;367:377-8.

43. Angrist M, Bolk S, Thiel B, Puffenberger EG, Hofstra RM, Buys CH, Cass DT, Chakravarti A. Mutation analysis of the RET receptor tyrosine kinase in Hirschsprung disease. Hum Mol Genet 1995;4:821-30.

44. Attie T, Pelet A, Edery P, Eng C, Mulligan LM, Amiel J, Boutrand L, Beldjord C, Nihoul-Fekete C, Munnich A, et al. Diversity of RET proto-oncogene mutations in familial and sporadic Hirschsprung disease. Hum Mol Genet 1995;4:1381-6.

45. Seri M, Yin L, Barone V, Bolino A, Celli I, Bocciardi R, Pasini B, Ceccherini I, Lerone M, Kristoffersson U, Larsson LT, Casasa JM, Cass DT, Abramowicz MJ, Vanderwinden JM, Kravcenkiene I, Baric I, Silengo M, Martucciello G, Romeo G. Frequency of RET mutations in long- and short-segment Hirschsprung disease. Hum Mutat 1997;9:243-9.

46. Hofstra RM, Wu Y, Stulp RP, Elfferich P, Osinga J, Maas SM, Siderius L, Brooks AS, vd Ende JJ, Heydendael VM, Severijnen RS, Bax KM, Meijers C, Buys CH. RET and GDNF gene scanning in Hirschsprung patients using two dual denaturing gel systems. Hum Mutat 2000:15:418-29.

47. Mulligan LM, Eng C, Attie T, Lyonnet S, Marsh DJ, Hyland VJ, Robinson BG, Frilling A, Verellen-Dumoulin C, Safar A, et al. Diverse phenotypes associated with exon 10 mutations of the RET proto- oncogene. Hum Mol Genet 1994:3:2163-7.

48. Eng C, Smith DP, Mulligan LM, Nagai MA, Healey CS, Ponder MA, Gardner E, Scheumann GF, Jackson CE, Tunnacliffe A, et al. Point mutation within the tyrosine kinase domain of the RET proto- oncogene in multiple endocrine neoplasia type 2B and related sporadic tumours [erratum in Hum Mol Genet 1994;3:686]. Hum Mol Genet 1994:3:237-41.

49. Hofstra RM, Landsvater RM, Ceccherini I, Stulp R, Stelwagen T, Luo Y, Pasini B, Hoppener JW, van Amstel HKGR. A mutation in the RET proto-oncogene associated with multiple endocrine neoplasia type $2 \mathrm{~B}$ and sporadic medullary thyroid carcinoma. Nature 1994;367:375-6.

50. Carlson KM, Dou S, Chi D, Scavarda N, Toshima K, Jackson CE, Wells SAJ, Goodfellow PJ, Donis-Keller H. Single missense mutation in the tyrosine kinase catalytic domain of the RET protooncogene is associated with multiple endocrine neoplasia type 2B. Proc Natl Acad Sci U S A 1994;91:1579-83.

51. Plaza Menacho I, Koster R, van der Sloot AM, Quax WJ, Osinga J, van der Sluis T, Hollema H, Burzynski GM, Gimm 0, Buys CH, Eggen BJ, Hofstra RM. RET-familial medullary thyroid carcinoma mutants Y791F and S891A activate a Src/JAK/STAT3 pathway, independent of glial cell line-derived neurotrophic factor. Cancer Res 2005:65:1729-37.

52. Santoro M, Carlomagno F, Romano A, Bottaro DP, Dathan NA, Grieco M, Fusco A, Vecchio G, Matoskova B, Kraus MH. Activation of RET as a dominant transforming gene by germline mutations of MEN2A and MEN2B. Science 1995;267:381-3.

53. Pasini B, Borrello MG, Greco A, Bongarzone I, Luo Y, Mondellini P, Alberti L, Miranda C, Arighi E, Bocciardi R, et al. Loss of function effect of RET mutations causing Hirschsprung disease. Nat Genet 1995:10:35-40.

54. Carlomagno F, De Vita G, Berlingieri MT, de Franciscis V, Melillo RM, Colantuoni V, Kraus MH, Di Fiore PP, Fusco A, Santoro M. Molecular heterogeneity of RET loss of function in Hirschsprung's disease. Embo J 1996;15:2717-25.

55. Iwashita T, Murakami H, Asai N, Takahashi M. Mechanism of ret dysfunction by Hirschsprung mutations affecting its extracellular domain. Hum Mol Genet 1996:5:1577-80.

56. Pelet A, Geneste 0, Edery P, Pasini A, Chappuis S, Atti T, Munnich A, Lenoir G, Lyonnet $S$, Billaud M. Various mechanisms cause RET-mediated signaling defects in Hirschsprung's disease. J Clin Invest 1998;101:1415-23.
57. Iwashita T, Kurokawa K, Qiao S, Murakami H, Asai N, Kawai K, Hashimoto M, Watanabe T, Ichihara M, Takahashi M. Functional analysis of RET with Hirschsprung mutations affecting its kinase domain. Gastroenterology 2001;121:24-33.

58. Manie S, Santoro M, Fusco A, Billaud M. The RET receptor: function in development and dysfunction in congenital malformation. Trends Genet 2001:17:580-9.

59. Lantieri F, Griseri P, Ceccherini I. Molecular mechanisms of RET-induced Hirschsprung pathogenesis. Ann Med 2006;38:11-19.

60. Sancandi M, Ceccherini I, Costa M, Fava M, Chen B, Wu Y, Hofstra R, Laurie T, Griffths M, Burge D, Tam PK. Incidence of RET mutations in patients with Hirschsprung's disease. J Pediatr Surg 2000;35:139-42; discussion 142-3.

61. Garcia-Barcelo M, Sham MH, Lee WS, Lui VC, Chen BL, Wong KK, Wong JS, Tam PK. Highly recurrent RET mutations and novel mutations in genes of the receptor tyrosine kinase and endothelin receptor B pathways in Chinese patients with sporadic Hirschsprung disease. Clin Chem 2004;50:93-100.

62. Bolk S, Pelet A, Hofstra RM, Angrist M, Salomon R, Croaker D, Buys CH, Lyonnet S, Chakravarti A. A human model for multigenic inheritance: phenotypic expression in Hirschsprung disease requires both the RET gene and a new 9q31 locus. Proc Natl Acad Sci U S A 2000;97:268-73.

63. Fitze G, Schreiber M, Kuhlisch E, Schackert HK, Roesner D. Association of RET protooncogene codon 45 polymorphism with Hirschsprung disease. Am J Hum Genet 1999;65:1469-73.

64. Borrego S, Saez ME, Ruiz A, Gimm 0, Lopez-Alonso M, Antinolo G, Eng C. Specific polymorphisms in the RET proto-oncogene are over-represented in patients with Hirschsprung disease and may represent loci modifying phenotypic expression. $J$ Med Genet 1999;36:771-4.

65. Borrego S, Ruiz A, Saez ME, Gimm 0, Gao X, Lopez-Alonso M, Hernandez A, Wright FA, Antinolo G, Eng C. RET genotypes comprising specific haplotypes of polymorphic variants predispose to isolated Hirschsprung disease. J Med Genet 2000;37:572-8.

66. Garcia-Barcelo M, Sham MH, Lui VC, Chen BL, Ott J, Tam PK. Association study of PHOX2B as a candidate gene for Hirschsprung's disease. Gut 2003;52:563-7.

67. Burzynski GM, Nolte IM, Osinga J, Ceccherini I, Twigt B, Maas S, Brooks A, Verheij J, Plaza Menacho I, Buys CH, Hofstra RM. Localizing a putative mutation as the major contributor to the development of sporadic Hirschsprung disease to the RET genomic sequence between the promoter region and exon 2. Eur J Hum Genet 2004; 12:604-12

68. Pelet A, de Pontual L, Clement-Ziza M, Salomon R, Mugnier C, Matsuda F, Lathrop M, Munnich A, Feingold J, Lyonnet S, Abel L, Amiel J. Homozygosity for a frequent and weakly penetrant predisposing allele at the RET locus in sporadic Hirschsprung disease. J Med Genet 2005;42:e18.

69. Borrego S, Fernandez RM, Dziema H, Niess A, Lopez-Alonso M, Antinolo G, Eng C. Investigation of germline GFRA4 mutations and evaluation of the involvement of GFRA1, GFRA2, GFRA3, and GFRA4 sequence variants in Hirschsprung disease. $J$ Med Genet 2003:40:e18.

70. Sancandi M, Griseri P, Pesce B, Patrone G, Puppo F, Lerone M, Martucciello G, Romeo G, Ravazzolo R, Devoto M, Ceccherini I. Single nucleotide polymorphic alleles in the $5^{\prime}$ region of the RET proto-oncogene define a risk haplotype in Hirschsprung's disease. J Med Genet 2003;40:714-8.

71. Garcia-Barcelo M, Ganster RW, Lui VC, Leon TY, So MT, Lau AM, Fu M, Sham MH, Knight J, Zannini MS, Sham PC, Tam PK. TTF-1 and RET promoter SNPs: regulation of RET transcription in Hirschsprung's disease. Hum Mol Genet 2005:14:191-204

72. Fernandez RM, Boru G, Pecina A, Jones K, Lopez-Alonso M, Antinolo G, Borrego S, Eng C. Ancestral RET haplotype associated with Hirschsprung's disease shows linkage disequilibrium breakpoint at -1249. J Med Genet 2005:42:322-7.

73. Fitze G, Paditz E, Schlafke M, Kuhlisch E, Roesner D, Schackert HK. Association of germline mutations and polymorphisms of the RET proto- oncogene with idiopathic congenital central hypoventilation syndrome in 33 patients. J Med Genet 2003; 40:E10.

74. Griseri P, Bachetti T, Puppo F, Lantieri F, Ravazzolo R, Devoto M, Ceccherini I. A common haplotype at the $5^{\prime}$ end of the RET proto-oncogene, overrepresented in Hirschsprung patients, is associated with reduced gene expression. Hum Mutat 2005:25:189-95.

75. Emison ES, McCallion AS, Kashuk CS, Bush RT, Grice E, Lin S, Portnoy ME, Cutler DJ, Green ED, Chakravarti A. A common sex-dependent mutation in a RET enhancer underlies Hirschsprung disease risk. Nature 2005;434:857-63.

76. Widlund HR, Fisher DE. Microphthalamia-associated transcription factor: a critical regulator of pigment cell development and survival. Oncogene 2003;22:3035-41.

77. Chattopadhyay $\mathbf{P}$, Pakstis AJ, Mukherjee N, lyengar S, Odunsi A, Okonofua F, Bonne-Tamir B, Speed W, Kidd JR, Kidd KK. Global survey of haplotype frequencies and linkage disequilibrium at the RET locus. Eur J Hum Genet 2003;11:760-9.

78. Griseri P, Sancandi M, Patrone G, Bocciardi R, Hofstra R, Ravazzolo R, Devoto M, Romeo G, Ceccherini I. A single-nucleotide polymorphic variant of the RET protooncogene is underrepresented in sporadic Hirschsprung disease. Eur J Hum Genet 2000:8:721-4.

79. Griseri P, Pesce B, Patrone G, Osinga J, Puppo F, Sancandi M, Hofstra R, Romeo G, Ravazzolo $R$, Devoto M, Ceccherini I. A rare haplotype of the RET proto-oncogene is a risk-modifying allele in Hirschsprung disease. Am J Hum Genet 2002:71:969-74.

80. Griseri P, Lantieri F, Puppo F, Bachetti T, Di Duca M, Ravazzolo R, Ceccherini I. A common variant located in the 3'UTR of the RET gene is associated with protection from Hirschsprung disease. Hum Mutat 2007;28:168-76. 
81. Ceccherini I, Bocciardi R, Luo Y, Pasini B, Hofstra R, Takahashi M, Romeo G. Exon structure and flanking intronic sequences of the human RET proto-oncogene. Biochem Biophys Res Commun 1993;196:1288-95.

82. Schuchardt A, D'Agati V, Larsson-Blomberg L, Costantini F, Pachnis V. Defects in the kidney and enteric nervous system of mice lacking the tyrosine kinase receptor Ret. Nature 1994;367:380-3.

83. Costantini F, Shakya R. GDNF/Ret signaling and the development of the kidney. Bioessays 2006;28:117-27.

84. Clarke JC, Patel SR, Raymond RM Jr, Andrew S, Robinson BG, Dressler GR, Brophy PD. Regulation of c-Ret in the developing kidney is responsive to Pax2 gene dosage. Hum Mol Genet 2006;15:3420-8.

85. Cao T, Shannon M, Handel MA, Etkin LD. Mouse ret finger protein (rfp) protooncogene is expressed at specific stages of mouse spermatogenesis. Dev Genet 1996;19:309-20.

86. Meng X, Lindahl M, Hyvonen ME, Parvinen M, de Rooij DG, Hess MW, RaatikainenAhokas A, Sainio K, Rauvala H, Lakso M, Pichel JG, Westphal H, Saarma M, Sariola $\mathrm{H}$. Regulation of cell fate decision of undifferentiated spermatogonia by GDNF. Science 2000:287:1489-93.

87. Jain S, Naughton CK, Yang M, Strickland A, Vij K, Encinas M, Golden J, Gupta A, Heuckeroth R, Johnson EM Jr, Milbrandt J. Mice expressing a dominant-negative Ret mutation phenocopy human Hirschsprung disease and delineate a direct role of Ret in spermatogenesis. Development 2004;131:5503-13.

88. Naughton CK, Jain S, Strickland AM, Gupta A, Milbrandt J. Glial cell-line derived neurotrophic factor-mediated RET signaling regulates spermatogonial stem cell fate. Biol Reprod 2006; 74:314-21.

89. Fukuyama S, Kiyono H. Neuroregulator RET initiates Peyer's-patch tissue genesis. Immunity 2007;26:393-5.

90. Veiga-Fernandes H, Coles MC, Foster KE, Patel A, Williams A, Natarajan D, Barlow A, Pachnis V, Kioussis D. Tyrosine kinase receptor RET is a key regulator of Peyer's patch organogenesis. Nature 2007;446:547-51.

91. de Graaff E, Srinivas S, Kilkenny C, D'Agati V, Mankoo BS, Costantini F, Pachnis V. Differential activities of the RET tyrosine kinase receptor isoforms during mammalian embryogenesis. Genes Dev 2001;15:2433-44.

92. Moore MW, Klein RD, Farinas I, Sauer H, Armanini M, Phillips H, Reichardt LF, Ryan AM, Carver-Moore K, Rosenthal A. Renal and neuronal abnormalities in mice lacking GDNF. Nature 1996;382:76-9.

93. Sanchez MP, Silos-Santiago I, Frisen J, He B, Lira SA, Barbacid M. Renal agenesis and the absence of enteric neurons in mice lacking GDNF. Nature 1996;382:70-3.

94. Pichel JG, Shen L, Sheng HZ, Granholm AC, Drago J, Grinberg A, Lee EJ, Huang SP, Saarma M, Hoffer BJ, Sariola H, Westphal H. Defects in enteric innervation and kidney development in mice lacking GDNF. Nature 1996;382:73-6.

95. Durbec P, Marcos-Gutierrez CV, Kilkenny C, Grigoriou M, Wartiowaara K, Suvanto P, Smith D, Ponder B, Costantini F, Saarma M, et al. GDNF signalling through the Ret receptor tyrosine kinase. Nature 1996;381:789-93.

96. Jing S, Wen D, Yu Y, Holst PL, Luo Y, Fang M, Tamir R, Antonio L, Hu Z, Cupples R, Louis JC, Hu S, Altrock BW, Fox GM. GDNF-induced activation of the ret protein tyrosine kinase is mediated by GDNFR-alpha, a novel receptor for GDNF. Cell 1996;85:1113-24.

97. Treanor JJ, Goodman L, de Sauvage F, Stone DM, Poulsen KT, Beck CD, Gray C, Armanini MP, Pollock RA, Hefti F, Phillips HS, Goddard A, Moore MW, Buj-Bello A, Davies AM, Asai N, Takahashi M, Vandlen R, Henderson CE, Rosenthal A. Characterization of a multicomponent receptor for GDNF. Nature 1996;382:80-3.

98. Rosenthal A. The GDNF protein family: gene ablation studies reveal what they really do and how. Neuron 1999;22:201-3.

99. Kotzbauer PT, Lampe PA, Heuckeroth RO, Golden JP, Creedon DJ, Johnson EM, Milbrandt J. Neurturin, a relative of glial-cell-line-derived neurotrophic factor. Nature 1996; 384:467-70

100. Milbrandt J, de Sauvage FJ, Fahrner TJ, Baloh RH, Leitner ML, Tansey MG, Lampe PA, Heuckeroth RO, Kotzbauer PT, Simburger KS, Golden JP, Davies JA, Vejsada R, Kato AC, Hynes M, Sherman D, Nishimura M, Wang LC, Vandlen R, Moffat B, Klein RD, Poulsen K, Gray C, Garces A, Johnson EM, et al. Persephin, a novel neurotrophic factor related to GDNF and neurturin. Neuron 1998;20:245-53.

101. Baloh RH, Tansey MG, Lampe PA, Fahrner TJ, Enomoto H, Simburger KS, Leitner ML, Araki T, Johnson EM, Milbrandt J. Artemin, a novel member of the GDNF ligand family, supports peripheral and central neurons and signals through the GFRalpha3RET receptor complex. Neuron 1998;21:1291-302.

102. Angrist M, Bolk S, Halushka M, Lapchak PA, Chakravarti A. Germline mutations in glial cell line-derived neurotrophic factor (GDNF) and RET in a Hirschsprung disease patient. Nat Genet 1996:14:341-4.

103. Salomon R, Attie T, Pelet A, Bidaud C, Eng C, Amiel J, Sarnacki S, Goulet O, Ricour C, Nihoul-Fekete C, Munnich A, Lyonnet S. Germline mutations of the RET ligand GDNF are not sufficient to cause Hirschsprung disease. Nat Genet 1996:14:345-7.

104. Ivanchuk SM, Myers SM, Eng C, Mulligan LM. De novo mutation of GDNF, ligand for the RET/GDNFR-alpha receptor complex, in Hirschsprung disease. Hum Mol Genet 1996;5:2023-6

105. Doray B, Salomon R, Amiel J, Pelet A, Touraine R, Billaud M, Attie T, Bachy B, Munnich A, Lyonnet $S$. Mutation of the RET ligand, neurturin, supports multigenic inheritance in Hirschsprung disease [erratum in Hum Mol Genet 1998;7:1831]. Hum Mol Genet 1998;7:1449-52.

106. Cacalano G, Farinas I, Wang LC, Hagler K, Forgie A, Moore M, Armanini M, Phillips $H$, Ryan AM, Reichardt LF, Hynes M, Davies A, Rosenthal A. GFRalpha1 is an essential receptor component for GDNF in the developing nervous system and kidney. Neuron 1998;21:53-62.
107. Enomoto H, Araki T, Jackman A, Heuckeroth RO, Snider WD, Johnson EM, Milbrandt J. GFR alpha1-deficient mice have deficits in the enteric nervous system and kidneys. Neuron 1998;21:317-24.

108. Angrist M, Jing S, Bolk S, Bentley K, Nallasamy S, Halushka M, Fox GM Chakravarti A. Human GFRA1: cloning, mapping, genomic structure, and evaluation as a candidate gene for Hirschsprung disease susceptibility. Genomics 1998:48:354-62.

109. Myers SM, Salomon R, Goessling A, Pelet A, Eng C, von Deimling A, Lyonnet S, Mulligan LM. Investigation of germline GFR alpha-1 mutations in Hirschsprung disease. J Med Genet 1999;36:217-20.

110. Bordeaux MC, Forcet C, Granger L, Corset V, Bidaud C, Billaud M, Bredesen DE, Edery P, Mehlen P. The RET proto-oncogene induces apoptosis: a novel mechanism for Hirschsprung disease. Embo J 2000;19:4056-63.

111. Inoue A, Yanagisawa M, Kimura S, Kasuya Y, Miyauchi T, Goto K, Masaki T. The human endothelin family: three structurally and pharmacologically distinct isopeptides predicted by three separate genes. Proc Natl Acad Sci U S A 1989;86:2863-7.

112. Sakurai T, Yanagisawa M, Masaki T. Molecular characterization of endothelin receptors. Trends Pharmacol Sci 1992;13:103-8.

113. Cohen IT, Gadd MA. Hirschsprung's disease in a kindred: a possible clue to the genetics of the disease. J Pediatr Surg 1982;17:632-4.

114. Puffenberger EG, Kauffman ER, Bolk S, Matise TC, Washington SS, Angrist M, Weissenbach J, Garver KL, Mascari M, Ladda R, et al. Identity-by-descent and association mapping of a recessive gene for Hirschsprung disease on human chromosome 13q22. Hum Mol Genet 1994;3:1217-25.

115. Van Camp G, Van Thienen MN, Handig I, Van Roy B, Rao VS, Milunsky A, Read AP Baldwin CT, Farrer LA, Bonduelle M, et al. Chromosome 13q deletion with Waardenburg syndrome: further evidence for a gene involved in neural crest function on 13q. J Med Genet 1995;32:531-6.

116. Shanske A, Ferreira JC, Leonard JC, Fuller P, Marion RW. Hirschsprung disease in an infant with a contiguous gene syndrome of chromosome 13. Am J Med Genet 2001;102:231-6

117. Hosoda K, Hammer RE, Richardson JA, Baynash AG, Cheung JC, Giaid A, Yanagisawa M. Targeted and natural (piebald-lethal) mutations of endothelin-B receptor gene produce megacolon associated with spotted coat color in mice. Cell 1994; 79:1267-76.

118. Puffenberger EG, Hosoda K, Washington SS, Nakao K, deWit D, Yanagisawa M, Chakravart A. A missense mutation of the endothelin-B receptor gene in multigenic Hirschsprung's disease. Cell 1994;79:1257-66.

119. Baynash AG, Hosoda K, Giaid A, Richardson JA, Emoto N, Hammer RE, Yanagisawa M. Interaction of endothelin-3 with endothelin-B receptor is essential for development of epidermal melanocytes and enteric neurons. Cell 1994;79:127785

120. Hofstra RM, Osinga J, Tan-Sindhunata G, Wu Y, Kamsteeg EJ, Stulp RP, van Ravenswaaii-Arts C, Majoor-Krakauer D, Angrist M, Chakravarti A, Meijers C, Buys $\mathrm{CH}$. A homozygous mutation in the endothelin-3 gene associated with a combined Waardenburg type 2 and Hirschsprung phenotype (Shah- Waardenburg syndrome). Nat Genet 1996;12:445-7.

121. Edery P, Attie T, Amiel J, Pelet A, Eng C, Hofstra RM, Martelli H, Bidaud C, Munnich A, Lyonnet S. Mutation of the endothelin-3 gene in the WaardenburgHirschsprung disease (Shah-Waardenburg syndrome). Nat Genet 1996;12:442-4.

122. Pingault V, Bondurand N, Kuhlbrodt $K$, Goerich DE, Prehu MO, Puliti A, Herbarth $B$, Hermans-Borgmeyer I, Legius E, Matthijs G, Amiel J, Lyonnet S, Ceccherini I, Romeo G, Smith JC, Read AP, Wegner M, Goossens M. SOX10 mutations in patients with Waardenburg-Hirschsprung disease. Nat Genet 1998;18:171-3.

123. Touraine RL, Attie-Bitach T, Manceau E, Korsch E, Sarda P, Pingault V, EnchaRazavi F, Pelet A, Auge J, Nivelon-Chevallier A, Holschneider AM, Munnes M, Doerfler W, Goossens M, Munnich A, Vekemans M, Lyonnet S. Neurological phenotype in Waardenburg syndrome type 4 correlates with novel SOX10 truncating mutations and expression in developing brain. Am J Hum Genet 2000;66:1496-503.

124. Southard-Smith EM, Angrist M, Ellison JS, Agarwala R, Baxevanis AD, Chakravarti A, Pavan WJ. The Sox10(Dom) mouse: modeling the genetic variation of Waardenburg- Shah (WS4) syndrome. Genome Res 1999;9:215-25.

125. Herbarth B, Pingault V, Bondurand N, Kuhlbrodt K, Hermans-Borgmeyer I, Puliti A Lemort N, Goossens M, Wegner M. Mutation of the Sry-related Sox10 gene in Dominant megacolon, a mouse model for human Hirschsprung disease. Proc Natl Acad Sci U S A 1998;95:5161-5.

126. Chakravarti A. Endothelin receptor-mediated signaling in Hirschsprung disease. Hum Mol Genet 1996:5:303-7.

127. Amiel J, Attie T, Jan D, Pelet A, Edery P, Bidaud C, Lacombe D, Tam P, Simeoni J, Flori E, Nihoul-Fekete C, Munnich A, Lyonnet S. Heterozygous endothelin receptor B (EDNRB) mutations in isolated Hirschsprung disease. Hum Mol Genet 1996;5:355-

128. Kusafuka T, Wang Y, Puri P. Novel mutations of the endothelin-B receptor gene in isolated patients with Hirschsprung's disease. Hum Mol Genet 1996;5:347-9,

129. Auricchio A, Casari G, Staiano A, Ballabio A. Endothelin-B receptor mutations in patients with isolated Hirschsprung disease from a non-inbred population. Hum Mol Genet 1996;5:351-4.

130. Bidaud C, Salomon R, Van Camp G, Pelet A, Attie T, Eng C, Bonduelle M, Amiel J, Nihoul-Fekete C, Willems PJ, Munnich A, Lyonnet S. Endothelin-3 gene mutations in isolated and syndromic Hirschsprung disease. Eur J Hum Genet 1997;5:247-51.

131. Hofstra RM, Valdenaire O, Arch E, Osinga J, Kroes H, Loffler BM, Hamosh A, Meijers C, Buys $\mathrm{CH}$. A loss-of-function mutation in the endothelin-converting enzyme 
1 (ECE- 1) associated with Hirschsprung disease, cardiac defects, and autonomic dysfunction. Am J Hum Genet 1999;64:304-8.

132. Yanagisawa $\mathbf{H}$, Yanagisawa M, Kapur RP, Richardson JA, Williams SC, Clouthier $\mathrm{DE}$, de Wit D, Emoto N, Hammer RE. Dual genetic pathways of endothelin-mediated intercellular signaling revealed by targeted disruption of endothelin converting enzyme-1 gene. Development 1998;125:825-36.

133. Lurie IW, Supovitz KR, Rosenblum-Vos LS, Wulfsberg EA. Phenotypic variability of del(2) (q22-q23): report of a case with a review of the literature. Genet Couns 1994;5:11-4.

134. Mowat DR, Croaker GD, Cass DT, Kerr BA, Chaitow J, Ades LC, Chia NL, Wilson MJ. Hirschsprung disease, microcephaly, mental retardation, and characteristic facial features: delineation of a new syndrome and identification of a locus at chromosome 2q22-q23. J Med Genet 1998;35:617-23.

135. Wakamatsu N, Yamada Y, Yamada K, Ono T, Nomura N, Taniguchi H, Kitoh H, Mutoh N, Yamanaka T, Mushiake K, Kato K, Sonta S, Nagaya M. Mutations in SIP1, encoding Smad interacting protein-1, cause a form of Hirschsprung disease. Nat Genet 2001:27:369-70.

136. Van de Putte T, Maruhashi M, Francis A, Nelles L, Kondoh H, Huylebroeck D, Higashi Y. Mice lacking ZFHX1B, the gene that codes for Smad-interacting protein1, reveal a role for multiple neural crest cell defects in the etiology of Hirschsprung disease-mental retardation syndrome. Am J Hum Genet 2003;72:465-70.

137. Trochet D, O'Brien LM, Gozal D, Trang H, Nordenskjold A, Laudier B, Svensson PJ, Uhrig S, Cole T, Munnich A, Gaultier C, Lyonnet S, Amiel J. PHOX2B genotype allows for prediction of tumor risk in congenital central hypoventilation syndrome. Am J Hum Genet 2005;76:421-6.

138. Trang H, Dehan M, Beaufils F, Zaccaria I, Amiel J, Gaultier C. The French Congenital Central Hypoventilation Syndrome Registry: general data, phenotype, and genotype. Chest 2005;127:72-9.

139. Pattyn A, Morin X, Cremer H, Goridis C, Brunet JF. The homeobox gene Phox2b is essential for the development of autonomic neural crest derivatives. Nature 1999;399:366-70.

140. Dauger S, Pattyn A, Lofaso F, Gaultier C, Goridis C, Gallego J, Brunet JF. Phox2b controls the development of peripheral chemoreceptors and afferent visceral pathways. Development 2003;130:6635-42.

141. Peippo MM, Simola KO, Valanne LK, Larsen AT, Kahkonen M, Auranen MP Ignatius J. Pitt-Hopkins syndrome in two patients and further definition of the phenotype. Clin Dysmorphol 2006;15:47-54.

142. Amiel J, Rio M, de Pontual L, Redon R, Malan V, Boddaert N, Plouin P, Carter NP, Lyonnet S, Munnich A, Colleaux L. Mutations in TCF4, encoding a class I basic helixloop-helix transcription factor, are responsible for Pitt-Hopkins syndrome, a severe epileptic encephalopathy associated with autonomic dysfunction. Am J Hum Genet 2007; 80:988-93.

143. Zweier C, Peippo MM, Hoyer J, Sousa S, Bottani A, Clayton-Smith J, Reardon W, Saraiva J, Cabral A, Gohring I, Devriendt K, de Ravel T, Bijlsma EK, Hennekam RC, Orrico A, Cohen M, Dreweke A, Reis A, Nurnberg P, Rauch A. Haploinsufficiency of TCF4 causes syndromal mental retardation with intermittent hyperventilation (PittHopkins syndrome). Am J Hum Genet 2007;80:994-1001.

144. Wang G, Zhang SH, Lin HJ, Tong EC, Huang YH, Huang GT, Zhuang FT. Nonoperative treatment of Hirschsprung's disease: a new approach. J Pediatr Surg 1987;22:439-42.

145. Bergqvist I, Eriksson M, Saarikettu J, Eriksson B, Corneliussen B, Grundstrom T Holmberg D. The basic helix-loop-helix transcription factor E2-2 is involved in T lymphocyte development. Eur J Immunol 2000;30:2857-63.

146. Fewtrell MS, Tam PK, Thomson AH, Fitchett M, Currie J, Huson SM, Mulligan LM. Hirschsprung's disease associated with a deletion of chromosome 10 (q11.2q21.2): a further link with the neurocristopathies? J Med Genet 1994;31:325-7.

147. McMilin KD, Reiss JA, Brown MG, Black MH, Buckmaster DA, Durum CT, Gunter KA, Lawce HJ, Berry TL, Lamb OA, Olson CL, Weeks FF, Yoshitomi MJ, Jacky PB, Olson SB, Magenis RE. Clinical outcomes of four patients with microdeletion in the long arm of chromosome 2. Am J Med Genet 1998;78:36-43.

148. de Pontual L, Pelet A, Clement-Ziza M, Trochet D, Antonarakis SE, Attie-Bitach T, Beales PL, Blouin JL, Dastot-Le Moal F, Dollfus H, Goossens M, Katsanis N, Touraine R, Feingold J, Munnich A, Lyonnet S, Amiel J. Epistatic interactions with a common hypomorphic RET allele in syndromic Hirschsprung disease. Hum Mutat 2007;28:790-796.

149. Brewer C, Holloway S, Zawalnyski P, Schinzel A, FitzPatrick D. A chromosomal deletion map of human malformations. Am J Hum Genet 1998;63:1153-9.

150. Brewer C, Holloway S, Zawalnyski P, Schinzel A, FitzPatrick D. A chromosomal duplication map of malformations: regions of suspected haplo- and triplolethalityand tolerance of segmental aneuploidy-in humans. Am J Hum Genet 1999:64:1702-8.

151. Mahboubi S, Templeton JM Jr. Association of Hirschsprung's disease and imperforate anus in a patient with "cat-eye" syndrome. A report of one case and review of the literature. Pediatr Radiol 1984:14:441-2.

152. Lane PW, Liu HM. Association of megacolon with a new dominant spotting gene (Dom) in the mouse. J Hered 1984;75:435-9.

153. Bondurand N, Kuhlbrodt K, Pingault V, Enderich J, Sajus M, Tommerup N, Warburg M, Hennekam RC, Read AP, Wegner M, Goossens M. A molecular analysis of the vemenite deaf-blind hypopigmentation syndrome: SOX10 dysfunction causes different neurocristopathies. Hum Mol Genet 1999;8:1785-9.

154. Inoue K, Khajavi M, Ohyama T, Hirabayashi S, Wilson J, Reggin JD, Mancias P, Butler IJ, Wilkinson MF, Wegner M, Lupski JR. Molecular mechanism for distinct neurological phenotypes conveyed by allelic truncating mutations. Nat Genet 2004;36:361-9.

155. Auricchio A, Griseri P, Carpentieri ML, Betsos N, Staiano A, Tozzi A, Priolo M, Thompson H, Bocciardi R, Romeo G, Ballabio A, Ceccherini l. Double heterozygosity for a RET substitution interfering with splicing and an EDNRB missense mutation in Hirschsprung disease. Am J Hum Genet 1999;64:1216-21.

156. Carrasquillo MM, McCallion AS, Puffenberger EG, Kashuk CS, Nouri N, Chakravarti A. Genome-wide association study in Mennonites identifies multiple genes for oligogenic Hirschsprung disease. Am J Hum Genet 2002;71:193.

157. Potterf SB, Furumura M, Dunn KJ, Arnheiter H, Pavan WJ. Transcription factor hierarchy in Waardenburg syndrome: regulation of MITF expression by SOX10 and PAX3. Hum Genet 2000;107:1-6.

158. Southard-Smith EM, Kos L, Pavan WJ. Sox10 mutation disrupts neural crest development in Dom Hirschsprung mouse model. Nat Genet 1998;18:60-4.

159. Stanchina L, Baral V, Robert F, Pingault V, Lemort N, Pachnis V, Goossens M, Bondurand N. Interactions between Sox10, Edn3 and Ednrb during enteric nervous system and melanocyte development. Dev Biol 2006;295:232-49.

160. Owens SE, Broman KW, Wiltshire T, Elmore JB, Bradley KM, Smith JR, SouthardSmith EM. Genome-wide linkage identifies novel modifier loci of aganglionosis in the Sox10Dom model of Hirschsprung disease. Hum Mol Genet 2005:14:1549-58.

161. Gabriel SB, Salomon R, Pelet A, Angrist M, Amiel J, Fornage M, Attie-Bitach T, Olson JM, Hofstra R, Buys C, Steffann J, Munnich A, Lyonnet S, Chakravarti A Segregation at three loci explains familial and population risk in Hirschsprung disease. Nat Genet 2002;31:89-93.

162. Brooks AS, Leegwater PA, Burzynski GM, Willems PJ, de Graaf B, van Langen I, Heutink P, Oostra BA, Hofstra RM, Bertoli-Avella AM. A novel susceptibility locus for Hirschsprung's disease maps to 4q31.3-q32.3. J Med Genet 2006;43:e35

163. Sakai T, Wakizaka A, Nirasawa Y, Ito Y. Point nucleotidic changes in both the RET proto-oncogene and the endothelin-B receptor gene in a Hirschsprung disease patient associated with Down syndrome. Tohoku J Exp Med 1999;187:43-7.

164. Sparkes RS, Sparkes MC, Kalina RE, Pagon RA, Salk DJ, Disteche CM. Separation of retinoblastoma and esterase $\mathrm{D}$ loci in a patient with sporadic retinoblastoma and del(13)(q14.1q22.3). Hum Genet 1984;68:258-9.

165. Lamont MA, Fitchett M, Dennis NR. Interstitial deletion of distal 13q associated with Hirschsprung's disease. J Med Genet 1989;26:100-4.

166. Bottani A, Xie YG, Binkert F, Schinzel A. A case of Hirschsprung disease with a chromosome 13 microdeletion, del(13)(q32.3q33.2): potential mapping of one disease locus. Hum Genet 1991;87:748-50.

167. Benailly H, Lapierre J, Laudier B, Amiel J, Attie T, De Blois M, Vekemans M, Romana S. PMX2B, a new candidate gene for Hirschsprung's disease. Clin Genet 2003;64:204-9

168. Attie T, Till M, Pelet A, Amiel J, Edery P, Boutrand L, Munnich A, Lyonnet S. Mutation of the endothelin-receptor $B$ gene in Waardenburg-Hirschsprung disease. Hum Mol Genet 1995:4:2407-9

169. Gross A, Kunze J, Maier RF, Stoltenburg-Didinger G, Grimmer I, Obladen M Autosomal-recessive neural crest syndrome with albinism, black lock, cell migration disorder of the neurocytes of the gut, and deafness: ABCD syndrome. Am J Med Genet 1995:56:322-6.

170. Mahakrishnan A, Srinivasan MS. Piebaldness with Hirschsprung's disease. Arch Dermatol 1980:116:1102

171. Kaplan P, de Chaderevian JP. Piebaldism-Waardenburg syndrome: histopathologic evidence for a neural crest syndrome. Am J Med Genet 1988;31:679-88.

172. Haddad GG, Mazza NM, Defendini R, Blanc WA, Driscoll JM, Epstein MA, Epstein RA, Mellins RB. Congenital failure of automatic control of ventilation, gastrointestinal motility and heart rate. Medicine (Baltimore) 1978;57:517-26.

173. Verloes A, Elmer C, Lacombe D, Heinrichs C, Rebuffat E, Demarquez JL, Moncla A Adam E. Ondine-Hirschsprung syndrome (Haddad syndrome). Further delineation in two cases and review of the literature. Eur J Pediatr 1993:152:75-7.

174. Amiel J, Laudier B, Attie-Bitach T, Trang H, de Pontual L, Gener B, Trochet D, Etchevers H, Ray P, Simonneau M, Vekemans M, Munnich A, Gaultier C, Lyonnet S. Polyalanine expansion and frameshift mutations of the paired-like homeobox gene PHOX2B in congenital central hypoventilation syndrome. Nat Genet 2003;33:459 61.

175. Verdy M, Weber AM, Roy CC, Morin CL, Cadotte M, Brochu P. Hirschsprung's disease in a family with multiple endocrine neoplasia type 2. J Pediatr Gastroenterol Nutr 1982:1:603-7.

176. Borst MJ, VanCamp JM, Peacock ML, Decker RA. Mutational analysis of multiple endocrine neoplasia type 2A associated with Hirschsprung's disease. Surgery 1995:117:386-91.

177. Caron P, Attie T, David D, Amiel J, Brousset F, Roger P, Munnich A, Lyonnet S C618R mutation in exon 10 of the RET proto-oncogene in a kindred with multiple endocrine neoplasia type 2A and Hirschsprung's disease. J Clin Endocrinol Metab 1996:81:2731-3

178. Peretz H, Luboshitsky R, Baron E, Biton A, Gershoni R, Usher S, Grynberg E, Yakobson E, Graff E, Lapidot M. Cys 618 Arg mutation in the RET proto-oncogene associated with familial medullary thyroid carcinoma and maternally transmitted Hirschsprung's disease suggesting a role for imprinting. Hum Mutat 1997:10:155-9

179. Decker RA, Peacock ML, Watson P. Hirschsprung disease in MEN 2A: increase spectrum of RET exon 10 genotypes and strong genotype-phenotype correlation. Hum Mol Genet 1998:7:129-34.

180. Romeo G, Ceccherini I, Celli J, Priolo M, Betsos N, Bonardi G, Seri M, Yin L, Lerone $\mathrm{M}$, Jasonni V, Martucciello G. Association of multiple endocrine neoplasia type 2 and Hirschsprung disease. J Intern Med 1998:243:515-20. 
181. Borrego S, Eng C, Sanchez B, Saez ME, Navarro E, Antinolo G. Molecular analysis of the ret and GDNF genes in a family with multiple endocrine neoplasia type 2A and Hirschsprung disease. J Clin Endocrinol Metab 1998;83:3361-4.

182. Goldberg RB, Shprintzen RJ. Hirschsprung megacolon and cleft palate in two sibs. J Craniofac Genet Dev Biol 1981;1:185-9.

183. Brooks AS, Breuning MH, Osinga J, vd Smagt JJ, Catsman CE, Buys CH, Meijers C, Hofstra RM. A consanguineous family with Hirschsprung disease, microcephaly, and mental retardation (Goldberg-Shprintzen syndrome). J Med Genet 1999:36:485-9.

184. Brooks AS, Bertoli-Avella AM, Burzynski GM, Breedveld GJ, Osinga J, Boven LG, Hurst JA, Mancini GM, Lequin MH, de Coo RF, Matera I, de Graaff E, Meijers C, Willems PJ, Tibboel D, Oostra BA, Hofstra RM. Homozygous nonsense mutations in KIAA1279 are associated with malformations of the central and enteric nervous systems. Am J Hum Genet 2005;77:120-6.

185. Santos H, Mateus J, Leal MJ. Hirschsprung disease associated with polydactyly, unilateral renal agenesis, hypertelorism, and congenital deafness: a new autosomal recessive syndrome. J Med Genet 1988;25:204-5.

186. Laurence KM, Prosser R, Rocker I, Pearson JF, Richard C. Hirschsprung's disease associated with congenital heart malformation, broad big toes, and ulnar polydactyly in sibs: a case for fetoscopy. J Med Genet 1975;12:334-8.

187. al-Gazali LI, Donnai D, Mueller RF. Hirschsprung's disease, hypoplastic nails, and minor dysmorphic features: a distinct autosomal recessive syndrome? J Med Genet 1988;25:758-61.

188. Huang T, Elias ER, Mulliken JB, Kirse DJ, Holmes LB. A new syndrome: Heart defect, laryngeal anomalies, preaxial polydactyly, and colonic aganglionosis in sibs. Genet Med 1999:1:104.

189. Reynolds JF, Barber JC, Alford BA, Chandler JG, Kelly TE. Familial Hirschsprung's disease and type $D$ brachydactyly: a report of four affected males in two generations. Pediatrics 1983:71:246-9.

190. Toriello HV, Komar K, Lawrence C, Higgins JV, Waterman DF. Macrocephaly, Hirschsprung disease, brachydactyly, vertebral defects, and other minor anomalies. Dysmorphology and Clinical Genetics 1988;1:155-7.

191. Cacheux V, Dastot-Le Moal F, Kaariainen H, Bondurand N, Rintala R, Boissier B, Wilson M, Mowat D, Goossens M. Loss-of-function mutations in SIP1 Smad interacting protein 1 result in a syndromic Hirschsprung disease. Hum Mol Genet 2001;10:1503-10.

192. Amiel J, Espinosa-Parrilla Y, Steffann J, Gosset P, Pelet A, Prieur M, Boute O Choiset A, Lacombe D, Philip N, Le Merrer M, Tanaka H, Till M, Touraine R, Toutain A, Vekemans M, Munnich A, Lyonnet S. Large-scale deletions and SMADIP1 truncating mutations in syndromic Hirschsprung disease with involvement of midline structures. Am J Hum Genet 2001;69:1370-7.

193. Zweier C, Thiel CT, Dufke A, Crow YJ, Meinecke P, Suri M, Ala-Mello S, Beemer F, Bernasconi S, Bianchi P, Bier A, Devriendt K, Dimitrov B, Firth H, Gallagher RC, Garavelli L, Gillessen-Kaesbach G, Hudgins L, Kaariainen H, Karstens S, Krantz I, Mannhardt A, Medne L, Mucke J, Kibaek M, Krogh LN, Peippo M, Rittinger O, Schulz S, Schelley SL, Temple IK, Dennis NR, Van der Knaap MS, Wheeler P, Yerushalmi B, Zenker M, Seidel H, Lachmeijer A, Prescott T, Kraus C, Lowry RB, Rauch A. Clinical and mutational spectrum of Mowat-Wilson syndrome. Eur J Med Genet 2005;48:97-111.

194. Radetti G, Frick R, Pasquino B, Mengarda G, Savage MO. Hypothalamic-pituitary dysfunction and Hirschsprung's disease in the Bardet-Biedl syndrome. Helv Paediatr Acta 1988;43:249-52.

195. Lorda-Sanchez I, Ayuso C, Ibanez A. Situs inversus and Hirschsprung disease: two uncommon manifestations in Bardet-Biedl syndrome. Am J Med Genet 2000;90:80-1.

196. Davenport M, Taitz LS, Dickson JA. The Kaufman-McKusick syndrome: another association. J Pediatr Surg 1989;24:1192-4.

197. Patterson K, Toomey KE, Chandra RS. Hirschsprung disease in a 46,XY phenotypic infant girl with Smith-Lemli-Opitz syndrome. J Pediatr 1983;103:425-7.

198. Makitie 0. [Cartilage-hair hypoplasia-a Finnish growth disorder]. Duodecim 1993;109:1638-46.

199. Okamoto N, Del Maestro R, Valero R, Monros E, Poo P, Kanemura Y Yamasaki M. Hydrocephalus and Hirschsprung's disease with a mutation of L1CAM. J Hum Genet 2004; 49:334-7

200. Mandel H, Brik R, Ludatscher R, Braun J, Berant M. Congenital muscular dystrophy with neurological abnormalities: association with Hirschsprung disease. Am J Med Genet 1993; 47:37-40.

201. Kim JJ, Armstrong DD, Fishman MA. Multicore myopathy, microcephaly, aganglionosis, and short stature. J Child Neurol 1994;9:275-7.

202. Mallory SB, Haynie LS, Williams ML, Hall W. Ichthyosis, deafness, and Hirschsprung's disease. Pediatr Dermatol 1989;6:24-7.

203. Kaplan P. X linked recessive inheritance of agenesis of the corpus callosum. J Med Genet 1983:20:122-4.

204. Okamoto N, Wada Y, Goto M. Hydrocephalus and Hirschsprung's disease in a patient with a mutation of L1CAM. J Med Genet 1997;34:670-1.

205. Hall CM. Werner's mesomelic dysplasia with ventricular septal defect and Hirschsprung's disease. Pediatr Radiol 1981;10:247-9.

206. Goldenberg A, Milh $M$, de Lagausie P, Mesnage R, Benarif F, de Blois MC Munnich A, Lyonnet S, Cormier-Daire V. Werner mesomelic dysplasia with Hirschsprung disease. Am J Med Genet A 2003;123:186-9.

207. Aurora $\mathbf{P}$, Wallis CE. Jeune syndrome (asphyxiating thoracic dystrophy) associated with Hirschsprung disease. Clin Dysmorphol 1999;8:259-63.

208. Hansford JR, Mulligan LM. Multiple endocrine neoplasia type 2 and RET: from neoplasia to neurogenesis. J Med Genet 2000;37:817-27.
209. Chatten J, Voorhess ML. Familial neuroblastoma. Report of a kindred with multiple disorders, including neuroblastomas in four siblings. N Engl J Med 1967:277:1230 6.

210. Clausen N, Andersson P. Tommerup N. Familial occurrence of neuroblastoma, von Recklinghausen's neurofibromatosis, Hirschsprung's agangliosis and jaw-winking syndrome. Acta Paediatr Scand 1989;78:736-41.

211. Knudson AG Jr, Meadows AT. Developmental genetics of neuroblastoma. J Natl Cancer Inst 1976;57:675-82.

212. Rohrer T, Trachsel D, Engelcke G, Hammer J. Congenital central hypoventilation syndrome associated with Hirschsprung's disease and neuroblastoma: case of multiple neurocristopathies. Pediatr Pulmonol 2002;33:71-6.

213. Trochet D, Bourdeaut F, Janoueix-Lerosey I, Deville A, de Pontual L, Schleiermacher G, Coze C, Philip N, Frebourg T, Munnich A, Lyonnet S, Delattre 0 Amiel J. Germline mutations of the paired-like homeobox 2B (PHOX2B) gene in neuroblastoma. Am J Hum Genet 2004;74:761-4.

214. Mosse YP, Laudenslager M, Khazi D, Carlisle AJ, Winter CL, Rappaport E, Maris JM. Germline PHOX2B mutation in hereditary neuroblastoma. Am J Hum Genet 2004; 75:727-30

215. van Limpt V, Schramm A, van Lakeman A, Sluis P, Chan A, van Noesel M, Baas F, Caron $\mathrm{H}$, Eggert $A$, Versteeg $R$. The Phox2B homeobox gene is mutated in sporadic neuroblastomas. Oncogene 2004;23:9280-8.

216. Perri P, Bachetti T, Longo L, Matera I, Seri M, Tonini GP, Ceccherini I. PHOX2B mutations and genetic predisposition to neuroblastoma. Oncogene 2005;24:3050-3.

217. McConville C, Reid S, Baskcomb L, Douglas J, Rahman N. PHOX2B analysis in non-syndromic neuroblastoma cases shows novel mutations and genotypephenotype associations. Am J Med Genet A 2006;140:1297-301.

218. Gozal D. Congenital central hypoventilation syndrome: an update. Pediatr Pulmonol 1998;26:273-82

219. Roshkow JE, Haller JO, Berdon WE, Sane SM. Hirschsprung's disease, Ondine's curse, and neuroblastoma- manifestations of neurocristopathy. Pediatr Radio 1988; 19:45-9.

220. Levard G, Boige N, Vitoux C, Aigrain Y, Boureau M, Navarro J. [Neurocristopathy. The association of Hirschsprung's disease-ganglioneuroma with autonomic nervous system dysfunction in 2 children]. Arch Fr Pediatr 1989;46:595-7.

221. Weese-Mayer DE, Silvestri JM, Marazita ML, Hoo JJ. Congenital central hypoventilation syndrome: inheritance and relation to sudden infant death syndrome. Am J Med Genet 1993:47:360-7.

222. Croaker GD, Shi E, Simpson E, Cartmill T, Cass DT. Congenital central hypoventilation syndrome and Hirschsprung's disease. Arch Dis Child 1998;78:31622.

223. Weese-Mayer DE, Berry-Kravis EM, Zhou L, Maher BS, Silvestri JM, Curran ME, Marazita ML. Idiopathic congenital central hypoventilation syndrome: analysis of genes pertinent to early autonomic nervous system embryologic development and identification of mutations in PHOX2b. Am J Med Genet 2003;123A:267-78.

224. Matera I, Bachetti T, Puppo F, Di Duca M, Morandi F, Casiraghi GM, Cilio MR, Hennekam R, Hofstra R, Schober JG, Ravazzolo R, Ottonello G, Ceccherini I. PHOX2B mutations and polyalanine expansions correlate with the severity of the respiratory phenotype and associated symptoms in both congenital and late onset Central Hypoventilation syndrome. J Med Genet 2004;41:373-80.

225. Weese-Mayer DE, Berry-Kravis EM, Zhou L. Adult identified with congenita central hypoventilation syndrome-mutation in PHOX2b gene and late-onset CHS. Am J Respir Crit Care Med 2005;171:88.

226. Waardenburg PJ. A new syndrome combining developmental anomalies of the eyelids, eyebrows and nose root with pigmentary defects of the iris and head hair and with congenital deafness. Am J Hum Genet 1951:3:195-253.

227. Hageman MJ, Delleman JW. Heterogeneity in Waardenburg syndrome. Am J Hum Genet 1977;29:468-85.

228. Jacobs JM, Wilson J. An unusual demyelinating neuropathy in a patient with Waardenburg's syndrome. Acta Neuropathol (Berl) 1992;83:670-4.

229. Weinberg AG, Currarino G, Besserman AM. Hirschsprung's disease and congenital deafness. Familial assocation. Hum Genet 1977:38:157-61.

230. Brunoni D, Joffe R, Farah LM, Cunha AJ. Syndrome identification case report 92 Hirschsprung megacolon, cleft lip and palate, mental retardation, and minor congenital malformations. J Clin Dysmorphol 1983;1:20-2.

231. Merkler RG, Solish SB, Scherzer AL. Meningomyelocele and Hirschprung disease: theoretical and clinical significance. Pediatrics 1985:76:299-300.

232. Papin C, van Grunsven LA, Verschueren K, Huylebroeck D, Smith JC. Dynamic regulation of Brachyury expression in the amphibian embryo by XSIP1. Mech Dev 2002:111(1-2):37-46

233. Van de Putte T, Francis A, Nelles L, van Grunsven LA, Huylebroeck D. Neural crest specific removal of Zfhx $1 \mathrm{~b}$ in mouse leads to a wide range of neurocristopathies reminiscent of Mowat-Wilson syndrome. Hum Mol Genet 2007;16:1423-36.

234. Hurst JA, Markiewicz M, Kumar D, Brett EM. Unknown syndrome: Hirschsprung's disease, microcephaly, and iris coloboma: a new syndrome of defective neuronal migration. J Med Genet 1988;25:494-7.

235. Halal F, Morel J. The syndrome of Hirschsprung disease, microcephaly, unusual face, and mental retardation. Am J Med Genet 1990:37:106-8.

236. Reish 0, Gorlin RJ, Hordinsky M, Rest EB, Burke B, Berry SA. Brain anomalies, retardation of mentality and growth, ectodermal dysplasia, skeletal malformations, Hirschsprung disease, ear deformity and deafness, eye hypoplasia, cleft palate, cryptorchidism, and kidney dysplasia/hypoplasia (BRESEK/BRESHECK): new X-linked syndrome? Am J Med Genet 1997:68:386-90. 
237. Tobin JL, Beales PL. Bardet-Biedl syndrome: beyond the cilium. Pediatr Nephrol 2007;22:926-36.

238. Stone DL, Slavotinek A, Bouffard GG, Banerjee-Basu S, Baxevanis AD, Barr M, Biesecker LG. Mutation of a gene encoding a putative chaperonin causes McKusickKaufman syndrome. Nat Genet 2000;25:79-82.

239. Slavotinek AM, Stone EM, Mykytyn K, Heckenlively JR, Green JS, Heon E, Musarella MA, Parfrey PS, Sheffield VC, Biesecker LG. Mutations in MKKS cause Bardet-Biedl syndrome. Nat Genet 2000;26:15-16.

240. Wassif CA, Maslen C, Kachilele-Linjewile S, Lin D, Linck LM, Connor WE, Steiner $\mathrm{RD}$, Porter FD. Mutations in the human sterol delta7-reductase gene at 11q12-13 cause Smith-Lemli-Opitz syndrome. Am J Hum Genet 1998;63:55-62.

241. Waterham HR, Wijburg FA, Hennekam RC, Vreken P, Poll-The BT, Dorland L, Duran M, Jira PE, Smeitink JA, Wevers RA, Wanders RJ. Smith-Lemli-Opitz syndrome is caused by mutations in the 7-dehydrocholesterol reductase gene. Am J Hum Genet 1998;63:329-38.

242. Sulisalo T, Sistonen P, Hastbacka J, Wadelius C, Makitie O, de la Chapelle A Kaitila I. Cartilage-hair hypoplasia gene assigned to chromosome 9 by linkage analysis. Nat Genet 1993:3:338-41.

243. de Pontual L, Pelet A, Trochet D, Jaubert F, Espinosa-Parrilla Y, Munnich A, Brunet JF, Goridis C, Feingold J, Lyonnet S, Amiel J. Mutations of the RET gene in isolated and syndromic Hirschsprung's disease in human disclose major and modifier alleles at a single locus. J Med Genet 2006;43:419-23.

244. Miao X, Garcia-Barcelo MM, So MT, Leon TY, Lau DK, Liu TT, Chan EK, Lan LC, Wong KK, Lui VC, Tam PK. Role of RET and PHOX2B gene polymorphisms in risk of Hirschsprung's disease in Chinese population. Gut 2007;56:736

245. Hofstra RM, Elfferich P. Osinga J, Verlind E, Fransen E, Lopez Pison J, de Die-Smulders CE, Stolte-Dijkstra I, Buys CH. Hirschsprung disease and
L1CAM: is the disturbed sex ratio caused by L1CAM mutations? J Med Genet 2002;39:E11.

246. Parisi MA, Kapur RP, Neilson I, Hofstra RM, Holloway LW, Michaelis RC, Leppig KA. Hydrocephalus and intestinal aganglionosis: is L1CAM a modifier gene in Hirschsprung disease? Am J Med Genet 2002;108:51-6.

247. Ikeda K, Goto S. Additional anomalies in Hirschsprung's disease: an analysis based on the nationwide survey in Japan. Z Kinderchir 1986;41:279-81.

248. Edward E, Ecker J, Christakis N, Folkman J. Hirschsprung's disease: associated abnormalities and demography. J Pediatr Surg 1992;27:76.

249. Russell MB, Russell CA, Niebuhr E. An epidemiological study of Hirschsprung's disease and additional anomalies. Acta Paediatr 1994;83:68-71.

250. Sarioglu A, Tanyel FC, Buyukpamukcu N, Hicsonmez A. Hirschsprung-associated congenital anomalies. Eur J Pediatr Surg 1997;7:331-7.

251. Lore F, Di Cairano G, Talidis F. Unilateral renal agenesis in a family with medullary thyroid carcinoma. N Engl J Med 2000;342:1218-9.

252. Whalen TV Jr, Asch MJ. Report of two patients with hypertrophic pyloric stenosis and Hirschsprung's disease. Coincident or common etiology? Am Surg 1985;51:480-1.

253. Sayed M, al-Alaiyan S. Agenesis of corpus callosum, hypertrophic pyloric stenosis and Hirschsprung disease: coincidence or common etiology? Neuropediatrics 1996;27:204-6.

254. Janik JP, Wayne ER, Janik JS, Price MR. Ileal atresia with total colonic aganglionosis. J Pediatr Surg 1997;32:1502-3.

255. McCallion AS, Stames E, Conlon RA, Chakravarti A. Phenotype variation in twolocus mouse models of Hirschsprung disease: tissue-specific interaction between Ret and Ednrb. Proc Natl Acad Sci U S A 2003:100:1826-31.

\title{
Date for your diary
}

\author{
International Forum on Quality \& Safety in Health Care \\ 22-25 April 2008 \\ Le Palais de Congrès de Paris \\ Paris, France \\ http://www.internationalforum.bmj.com \\ Why attend? \\ - Join over 1000 healthcare professionals from over 40 countries worldwide \\ - Learn from experienced leaders and improvement experts \\ - Find out what is current in quality and safety \\ - Gain new skills and tools for creating change in your organisation \\ - Take home practical solutions for improvement methods \\ - Network with like-minded colleagues
}

This is a premier event for those dedicated to improving quality and safety in healthcare. Our focus is on practical, take-home ideas that will leave you inspired to implement valuable, lasting change on your return to the workplace.

Register online from January 2008 onwards

For more information on the forum visit - http://www.internationalforum.bmj.com 